\title{
Germany: Financial Sector Assessment Program- Detailed Assessment of Observance on Insurance Core Principles
}

This Financial Sector Assessment Program-Detailed Assessment of Observance on Insurance Core Principles for Germany was prepared by a staff team of the International Monetary Fund as background documentation for the periodic consultation with the member country. It is based on the information available at the time it was completed in July, 2011. The views expressed in this document are those of the staff team and do not necessarily reflect the views of the government of Germany or the Executive Board of the IMF.

The policy of publication of staff reports and other documents by the IMF allows for the deletion of market-sensitive information.

\author{
Copies of this report are available to the public from \\ International Monetary Fund • Publication Services \\ $70019^{\text {th }}$ Street, N.W. • Washington, D.C. 20431 \\ Telephone: (202) 623-7430 • Telefax: (202) 623-7201 \\ E-mail: publications@imf.org Internet: http://www.imf.org
}

\section{International Monetary Fund Washington, D.C.}


FinANCial Sector Assessment Program Update GERMANY

\author{
INSURANCE CORE PRINCIPLES
}

\title{
DETAILED ASSESSMENT OF OBSERVANCE
}

JULY 2011 
Glossary .3

I. Executive Summary, Key Findings, and Recommendations 7

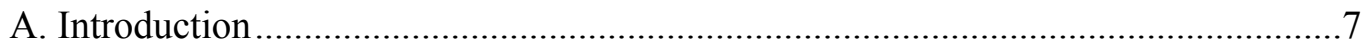

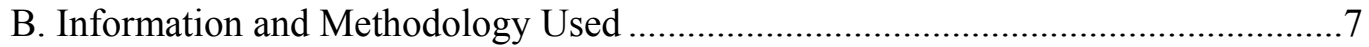

C. Institutional and Market Structure-Overview .............................................

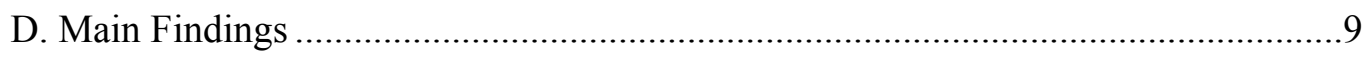

II. Recommended Action Plan and Authorities' Response ................................................14

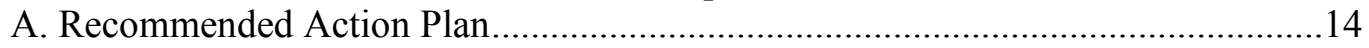

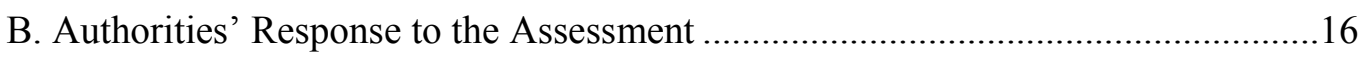

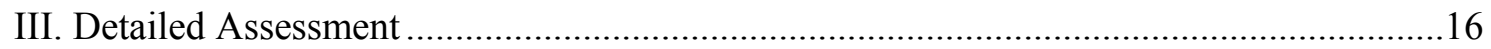

Tables

1. Summary of Main Findings of Assessment of Observance of the IAIS Insurance

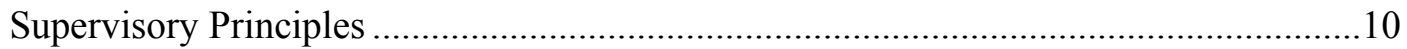

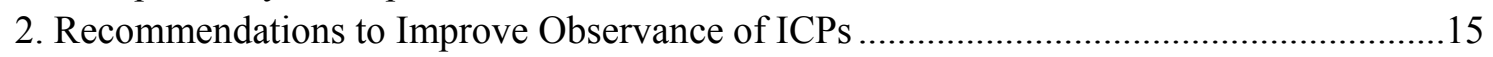

3. Detailed Assessment of Observance of the Insurance Core Principles ...............................16 


\section{GLOSSARY}

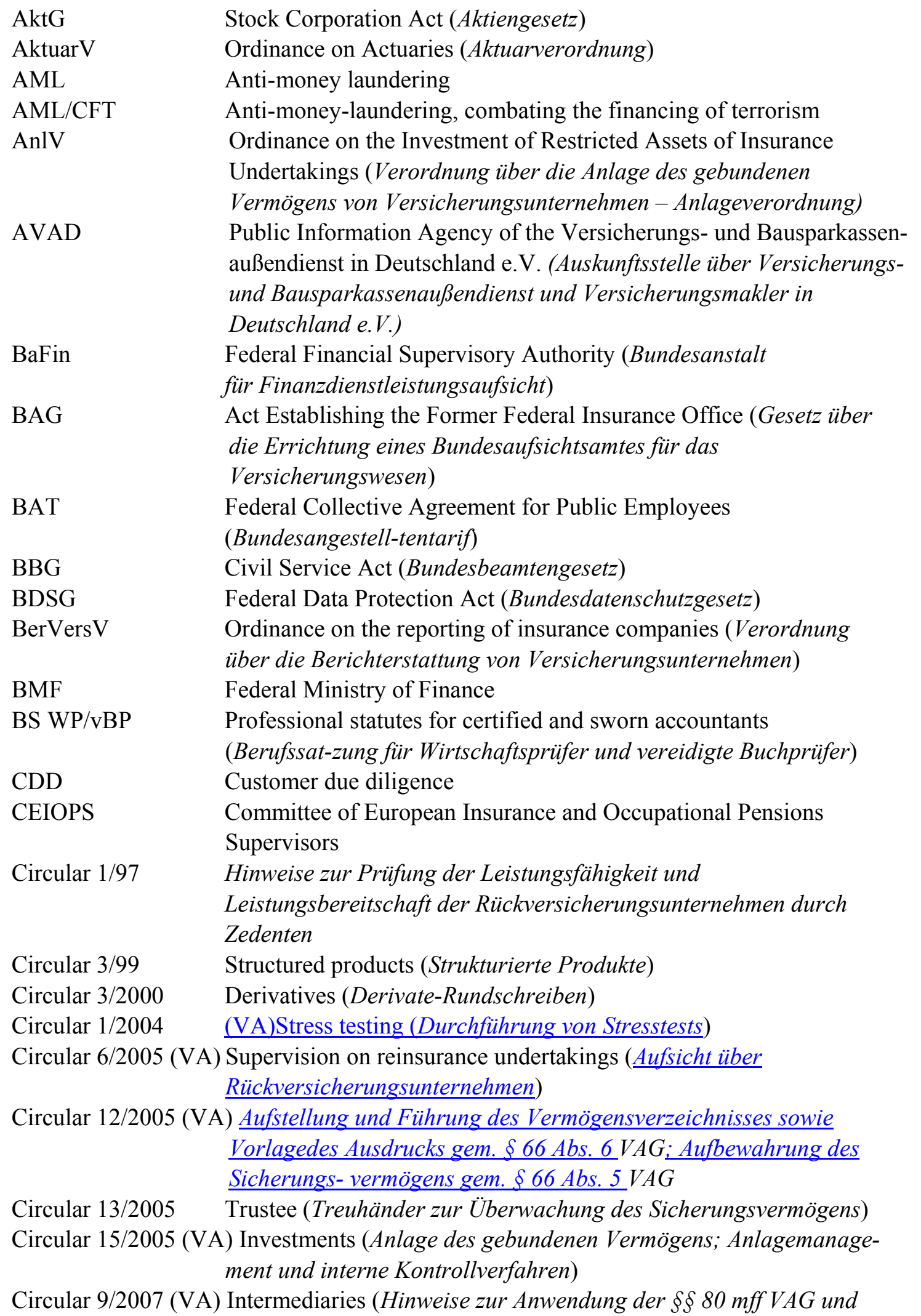


$\S 34 d$ Gewerbeordnung (Versicherungsvermittlerrecht))

Circular 3/2009 (VA) Risk management (Aufsichtsrechtliche Mindestanforderungen an das Risikomanagement (MaRisk VA))

Circular 14/2009 (GW) Due Dilligence (Anwendung der Sorgfaltspflichten im Zusammenhang mit der Drittlandäquivalenzliste etc.)

Circular 23/2009 (VA) Requirements for Remuneration Systems in the Insurance Industry (Anforderungen an Vergütungssysteme im Versicherungsbereich)

DAR

DAV

DeckRV

DESTATIS

DRSC

EEA

EIOPA

EU

EUREX

FATF

FinDAG

FinDAGKostV

FinRVV

FIU

FMStG

FMVAStärkG

FSAP

FSB

FT

GDV

GewO

GG

GoDirBaFin

GwG

HGB

IAIS

ICPs

IDW
Detailed assessment report

German Actuary Association (Deutsche Aktuar Vereinigung)

Mathematical provisions ordinance (Deckungsrückstellungsverord nung)

Federal Statistical Office (Statistisches Bundesamt)

German Accounting Standards Committee (Deutsches Rechnungsle

gungs Standards Committee e.V.)

European economic area

European Insurance and Occupational Pensions Authority

European Union

European Exchange (Handelsplattform für Optionen und Futures)

Financial Action Task Force

Act establishing the Federal Financial Supervisory Authority (BaFin)

(Finanzdienstleistungsaufsichtsgesetz)

Ordinance on the imposition of fees and allocation of costs pursuant to the FinDAG (Verordnung über die Erhebung von Gebühren und die Umlegung von Kosten nach dem Finanzdienstleistungsaufsichtsgesetz)

Finite Reinsurance Regulation (Finanzrückversicherungsverordnung)

Financial Intelligence Unit (Bundeskriminalamt)

Financial Market Stabilisation Act (Finanzmarktstabilisierungsgesetz)

Act for the Strengthening of the Financial Markets and Insurance

Supervision (Gesetz zur Stärkung der Finanzmarkt- und der

Versicherungsaufsicht)

Financial Sector Assessment Program

Financial Stability Board

Financing of terrorism

German Insurance Association (Gesamtverband der Deutschen

Versicherungswirtschaft e.V.)

Industrial Code (Gewerbeordnung)

Constitution of the Federal Republic of Germany (Grundgesetz)

Geschäftsordnung des Direktoriums der Bundesanstalt für

Finanzdienstleistungsaufsicht

Anti-Money Laundering Act (Gesetz über das Aufspüren von

Gewinnen aus schweren Straftaten - Geldwäschegesetz)

Commercial code (Handelsgesetzbuch)

International Association of Insurance Supervisors

Insurance Core Principles

Institute of German Certified Public Accountants (Institut der Wirt-

schaftsprüfer in Deutschland e.V.) 


\begin{tabular}{|c|c|}
\hline IFRS & International Financial Reporting Standards \\
\hline IHK & $\begin{array}{l}\text { Chambers of Industry and Commerce (Industrie- und } \\
\text { Handelskammer) }\end{array}$ \\
\hline IMF & International Monetary Fund \\
\hline InhKontrollV & $\begin{array}{l}\text { Holder Control Regulation (Verordnung über die Anzeigen nach } \S 2 c \\
\text { des Kreditwesengesetzes und } \S 104 \text { des } \\
\text { Versicherungsaufsichtsgesetzes - Inhaberkontrollverordnung) }\end{array}$ \\
\hline InsO & Insolvency Statute (Insolvenzordnung) \\
\hline ISVAP & Italian Insurance Supervisory Authority \\
\hline InvG & Investment Act (Investmentgesetz) \\
\hline KonTraG & $\begin{array}{l}\text { Law Concerning Control and Transparency of Corporations } \\
\text { (Gesetz zur Kontrolle und Transparenz im Unternehmensbereich) }\end{array}$ \\
\hline KWG & Banking Act (Gesetz über das Kreditwesen - Kreditwesengesetz) \\
\hline MaRisk VA & $\begin{array}{l}\text { Circular 3/2009 on the Minimum Requirements for Risk Management } \\
\text { in Insurance Undertakings (Mindestanforderungen an das } \\
\text { Risikomanagement in Versicherungsunternehmen) }\end{array}$ \\
\hline ML & Money laundering \\
\hline $\mathrm{MMoU}$ & $\begin{array}{l}\text { Multilateral Memorandum of Understanding on Cooperation and } \\
\text { Information Exchange }\end{array}$ \\
\hline $\mathrm{MoU}$ & Memorandum of Understanding \\
\hline PEP & Politically exposed person (politisch exponierte Person) \\
\hline PrüfV & Ordinance on Auditor's Reports (Prüfungsberichteverordnung) \\
\hline OsBaFin & $\begin{array}{l}\text { Organisational Statute of BaFin (Organisationsstatut für die } \\
\text { Bundesanstalt für Finanzdienstleistungsaufsicht }\end{array}$ \\
\hline OTC & Over-the-counter \\
\hline OWiG & $\begin{array}{l}\text { Act on Breaches of Administrative Regulations (Gesetz über } \\
\text { Ordnungswidrigkeiten) }\end{array}$ \\
\hline $\mathrm{RBC}$ & $\begin{array}{l}\text { Risk-based capital (gefordertes Solvabilitätskapital im Rahmen von } \\
\text { Risk-Based-Capital-Modellen) }\end{array}$ \\
\hline RechVersV & $\begin{array}{l}\text { Ordinance on Insurance Accounting (Verordnung über die } \\
\text { Rechnungslegung von Versicherungsunternehmen) }\end{array}$ \\
\hline SachVPrüfV & $\begin{array}{l}\text { Ordinance on Audits by Independent Experts } \\
\text { (Sachverständigenprüfordnung) }\end{array}$ \\
\hline StGB & Criminal Code (Strafgesetzbuch) \\
\hline STR & $\begin{array}{l}\text { Suspicious transactions report (Bericht über verdächtige } \\
\text { Transaktionen) }\end{array}$ \\
\hline UmwG & Reorganization of Companies Act (Umwandlungsgesetz) \\
\hline VAG & Insurance Supervision Act (Versicherungsaufsichtsgesetz) \\
\hline VAR & Value at Risk \\
\hline VersVermG & $\begin{array}{l}\text { Act amending the Insurance Mediation Law (Gesetz zur Neuregelung } \\
\text { des Versicherungsvermittlerrechts) }\end{array}$ \\
\hline VersVermV & $\begin{array}{l}\text { Insurance Mediation Ordinance (Versicherungsvermittlungsverord- } \\
\text { nung) }\end{array}$ \\
\hline VVaG & $\begin{array}{l}\text { Mutual insurance company (Versicherungsverein auf Gegenseitig- } \\
\text { keit) }\end{array}$ \\
\hline VVG & Insurance Contract Act (Versicherungsvertragsgesetz) \\
\hline
\end{tabular}


VVG Info-V Ordinance on Information Obligations for Insurance Contracts (Verordnung über Informationspflichten bei Versicherungsverträgen)

VwGO Code of Administrative Court Procedures

(Verwaltungsgerichtsordnung)

VwVfG

Administrative Procedure Act (Verwaltungsverfahrensgesetz)

$\mathrm{WpHG}$

Securities Trading Act (Wertpapierhandelsgesetz)

ZAG

Payment Services Supervisory Act (Zahlungsdiensteaufsichtsgesetz) 


\section{EXECUTIVE SUMMARY, KEY FINDINGS, AND RECOMMENDATIONS}

1. Insurance regulation and supervision is generally of a high standard, and most of the enhancements suggested in the 2003 assessment have been put in place. Further enhancements will need to be undertaken, in particular in the context of the forthcoming introduction of Solvency II requirements, in such areas as the frequency of on-site inspections, the enhancement of resources devoted to group-wide supervision, and stability analysis, for example, through sophisticated stress testing for larger insurers and improved group-wide stability analysis.

\section{A. Introduction}

2. This assessment of Germany's observance of the International Association of Insurance Supervisors (IAIS) Insurance Core Principles (ICPs) was carried out as part of the 2011 Financial Sector Assessment Program (FSAP) Update. The main mission took place in January-February 2011. The assessor was Fausto Parente of the Italian Insurance Supervisory Authority (ISVAP).

\section{B. Information and Methodology Used}

3. The assessment of Germany's observance of the ICPs was based on a review of the relevant laws and regulations in force at the time; discussions with the supervisors, other government bodies, and market participants; and additional material provided by the authorities. Because of strong legal restrictions on the sharing of institution-specific information, access to inspection reports and similar documents was limited. The authorities and market participants were uniformly cooperative.

4. The level of observance for each Principle reflects the assessments of the essential criteria only. Assessment of advanced criteria should not be included in assessing observance with principles. Subject to the caveat given below, a principle will be considered observed whenever all the essential criteria are considered to be observed or when all the essential criteria are observed except for a number that are considered not applicable. A principle will be considered to be not applicable when the essential criteria are considered to be not applicable.

5. With respect to an assessment of the principle that is other than observed or not applicable, similar guidance is to be used as applies to the criteria themselves. So, for a principle to be considered largely observed, it is necessary that only minor shortcomings exist which do not raise any concerns about the authority's ability to achieve full observance with the principle. A principle will be considered partly observed whenever, despite progress, the shortcomings are sufficient to raise doubts about the authority's ability to achieve observance. A principle will be considered not observed whenever no substantive progress toward observance has been achieved.

6. While it is generally expected that full observance of a principle would be achieved through the observance of the essential criteria, there may be instances where 
a member can demonstrate that observance with a principle has been achieved through different means. Conversely, due to specific conditions in a jurisdiction, meeting the essential criteria may not be sufficient to achieve observance of the objective of a principle. In these cases, additional measures are needed in order for observance of the particular principle to be considered effective.

7. The criteria should normally apply to all sectors of the insurance market. Where there are material differences between the levels of observance of a criterion between sectors that may lead different ratings being assigned to the sectors had the assessment been carried out separately (say, where a jurisdiction supervises primary insurers and not reinsurers), one may opt to present such differing ratings in this self-assessment program.

\section{Institutional and Market Structure-Overview}

8. The German Federal Financial Supervisory Authority (BaFin) is the insurance supervisor. The Federal Ministry of Finance (BMF) has legal and supervisory control over BaFin.

9. The supervision of insurance companies in Germany is based on the Insurance Supervision Act (VAG). Furthermore, insurers have to comply with other acts, codes, ordinances and circulars.

10. The insurance sector consisted of 621 companies at end-2010, comprising 98 life insurers, 265 nonlife insurers (including 48 health insurers), 152 Pensionskassen, 36 reinsurers, others including 40 death benefit funds and 30 Pensionsfonds. The 20 largest groups conduct the bulk of business; the five largest insurance groups alone receive about half of all premiums. The sector includes many small companies but also several of the world's largest primary insurers and reinsurers, some of whom receive less than half their profits from domestic operations. Of the sectors' roughly $€ 1.4$ trillion in total assets, $€ 804$ billion was held in life insurers at end-2009. The Pensionskassen and Pensionsfonds held roughly $€ 133$ billion in total assets at end-2009. Due to tax law changes, sales of traditional life insurance products (endowment policies) have recently declined, while those of certain types of annuities increased. The life insurance sector witnesses a pronounced trend to single premium contracts. This is attributed in part to the low interest rate environment and therefore low returns on many traditional investments. Despite the global financial crisis, soundness indicators have remained generally healthy across the insurance sector.

\section{The auditing and accounting rules applicable to financial institutions generally} comply with international standards. German listed companies apply as required the International Financial Reporting Standards (IFRS) since 2005. The German legislative framework with regard to the audit profession requires external auditors to be independent in both fact and appearance. The judicial system, including that for bankruptcy and the enforcement of property rights, is well developed. The payment and settlement system is reliable and efficient.

12. Germany has a solid institutional framework supporting the conduct of sound macroeconomic policies. Monetary policy is conducted within the European System of 
Central Banks framework. Budgetary policy is conducted within a fiscal framework based on predefined rules and within the requirements of the European Stability Pact. Germany was hit hard by the global crisis, mainly because of the economy's international connections, but at the time of the assessment a strong recovery was under way. Nonetheless, trend growth in potential output is relatively slow, and currently interest rates are unusually low.

\section{Main Findings}

13. The level of observance of these standards is very high. The authorities are aware that the size and sophistication of the German financial system demand that the supervision go beyond the standards, and they are working to make further improvements, especially those needed to implement the regulatory and financial policy initiatives that have been occasioned by the global crisis

\section{Insurance regulation and supervision is generally of a high standard, and most} of the enhancements suggested in the 2003 assessment have been put in place. For example, new rules have been issued to improve qualitative requirements posed on all the insurance undertakings in the area of corporate governance, risk management and internal control. Reinsurance companies are now subject to more extensive regulation and supervision, which, however, allow for the differences between them and primary insurers. The new regulations aims at anticipating some of the Pillar 2 requirements which will be implemented with Solvency II, paving the way for a smooth transition to the new risk-based solvency regime starting in 2013. A new risk-based system to select the priorities for the supervision as well as the efficient allocation of supervisory resources has been implemented.

\section{The authorities acknowledge the need to continue to develop supervisory}

capacity. The incoming prudential regime under Solvency II will require enhancement of BaFin supervisory resources (both in terms of quantity and quality). To these ends, the frequency of on-site inspection should be increased especially for insurers that are deemed to have a medium-sized market impact (current practice is to have an on-site inspection at least every eight years). Given the presence of large, cross-border insurance groups, group-wide supervision needs to be enhanced, as should the level of supervisory cooperation. In many of these areas, the further refinement of stress testing techniques would be helpful. The implementation of the European Union (EU) directive on insurance intermediaries is a major step towards ensuring adequate supervision of market conduct issues. However, the split of competences between BaFin and the local Chambers of Industry and Commerce should be reviewed to ensure against an effective market conduct supervision and consumer protection.

\section{Most of the requirements and supervisory tools which are in use for the} supervision of primary insurers are also applied to the reinsures. The most relevant exception is the investment activity, which is regulated on the basis of the "prudent person principle" to take into account the specific features of the reinsurance activity. This approach may have merit, but experience elsewhere suggests that vigilance is required in its application. 
Table 1. Germany: Summary of Main Findings of Assessment of Observance of the IAIS Insurance Supervisory Principles

\begin{tabular}{|c|c|c|}
\hline ICP & Grading & Comments \\
\hline $\begin{array}{l}\text { 1. Conditions for effective } \\
\text { insurance supervision. }\end{array}$ & 0 & $\begin{array}{l}\text { Insurance supervision in Germany is facilitated by } \\
\text { sound and progressive financial sector policy } \\
\text { framework and financial market infrastructure. }\end{array}$ \\
\hline 2. Supervisory objectives. & 0 & $\begin{array}{l}\text { The objectives fixed under the law are mainly } \\
\text { focused on the protection of the policyholders. } \\
\text { Consideration could be given to explicitly mention } \\
\text { systemic stability. }\end{array}$ \\
\hline 3. Supervisory authority. & LO & $\begin{array}{l}\text { BaFin is operationally independent and subject to } \\
\text { clear accountability mechanisms; its staff is } \\
\text { experienced and qualified. Public disclosure of the } \\
\text { reasons for dismissal of board members should be } \\
\text { required, although it is recognized that in practice } \\
\text { reasons would be given. It is recommended, } \\
\text { moreover, that the guidance for the control of } \\
\text { BaFin by the Federal Ministry of Finance be } \\
\text { reviewed to reduce the reporting burden. There is } \\
\text { also scope for strengthening regulatory resources, } \\
\text { particularly for supervision of internationally active } \\
\text { insurance groups and implementation of } \\
\text { Solvency II. }\end{array}$ \\
\hline 4. Supervisory process. & $\mathrm{O}$ & $\begin{array}{l}\text { BaFin is moving toward a more risk-based } \\
\text { supervisory approach, which will be fully in place } \\
\text { once Solvency II is implemented. For the time } \\
\text { being a risk model to select and prioritize the } \\
\text { supervisory analysis has been made operational. It } \\
\text { is recommended that it is further developed to } \\
\text { better take into account the supervision of } \\
\text { insurance groups. }\end{array}$ \\
\hline $\begin{array}{l}\text { 5. Supervisory cooperation } \\
\text { and information sharing. }\end{array}$ & $\mathrm{O}$ & $\begin{array}{l}\text { BaFin is empowered to, and does regularly } \\
\text { exchange information with other supervisors, both } \\
\text { within and beyond the EU. It's a signatory to the } \\
\text { EU/European Economic Area (EEA) Protocols on } \\
\text { supervisory cooperation, the IAIS multilateral } \\
\text { Memorandum of Understanding (MoU) as well as } \\
\text { of a number of bilateral MoUs. It is recommended } \\
\text { that the concrete application of the confidentiality } \\
\text { rules be monitored in order to avoid that it can } \\
\text { become an obstacle for full information sharing } \\
\text { among supervisors. }\end{array}$ \\
\hline 6. $\quad$ Licensing. & $\mathrm{O}$ & $\begin{array}{l}\text { The licensing regime, based on the EU directives, } \\
\text { is clear and transparent. }\end{array}$ \\
\hline 7. Suitability of persons. & LO & $\begin{array}{l}\text { BaFin performs robust due diligence on any } \\
\text { proposed significant owner, board members, } \\
\text { trustees and appointed actuaries prior to licensing } \\
\text { and after by also monitoring subsequent changes. } \\
\text { Consideration should be given to having the power }\end{array}$ \\
\hline
\end{tabular}




\begin{tabular}{|c|c|c|}
\hline ICP & Grading & Comments \\
\hline & & $\begin{array}{l}\text { to extend similar requirements, as needed, to other } \\
\text { high level managers who determine day-to-day } \\
\text { policies. Moreover, it is suggested that insurers be } \\
\text { required to report to BaFin as they become aware } \\
\text { of circumstances that may be relevant for the } \\
\text { fitness and propriety of key functionaries. }\end{array}$ \\
\hline $\begin{array}{l}\text { 8. Changes in control and } \\
\text { portfolio transfers. }\end{array}$ & $\mathrm{O}$ & $\begin{array}{l}\text { The conditions under which a qualified holding in } \\
\text { an insurance undertaking can be assumed are } \\
\text { clear and in line with the relevant EU directives. } \\
\text { Portfolio transfers must be approved by BaFin. }\end{array}$ \\
\hline 9. Corporate governance. & $\mathrm{O}$ & $\begin{array}{l}\text { BaFin has recently introduced new requirements } \\
\text { for insurers, which strengthened the robustness of } \\
\text { its assessment of insurers' corporate governance. } \\
\text { Those measures can be seen as an anticipation of } \\
\text { the Pillar } 2 \text { requirements, which will come into force } \\
\text { in } 2013 \text { under Solvency II. }\end{array}$ \\
\hline 10. Internal controls. & $\mathrm{O}$ & $\begin{array}{l}\text { BaFin has articulated clearly its supervisory } \\
\text { expectation of insurers in implementing appropriate } \\
\text { internal controls tailored to the nature, scale and } \\
\text { complexity of their operations. As for other areas of } \\
\text { the supervision, measures were introduced to } \\
\text { enhance the insurers' internal controls systems in } \\
\text { view of the incoming implementation of Solvency II. }\end{array}$ \\
\hline 11. Market analysis. & $\mathrm{O}$ & $\begin{array}{l}\text { BaFin performs market analysis and stress tests to } \\
\text { identify, assess, and mitigate risks to the insurance } \\
\text { sector. Quantitative analysis will need to be } \\
\text { enhanced and kept up to date, for example, } \\
\text { through more comprehensive stress testing for } \\
\text { larger insurers. }\end{array}$ \\
\hline 12. Reporting to supervisors. & $\mathrm{O}$ & $\begin{array}{l}\text { BaFin has a systematic process to review } \\
\text { regulatory returns and information provided by } \\
\text { insurers as part of its offsite surveillance. The } \\
\text { supervisory returns take advantage of the auditor } \\
\text { assessment performed on the financial statement. } \\
\text { It is advisable to introduce an explicit obligation on } \\
\text { auditors as well as on the insurer itself to inform } \\
\text { the supervisor promptly of any material changes } \\
\text { which affect the current or foreseeable financial } \\
\text { condition of an institution. }\end{array}$ \\
\hline 13. On-site inspection. & $\mathrm{O}$ & $\begin{array}{l}\text { BaFin conducts on-site inspections, which are } \\
\text { prioritized based on an analysis of insurers' risk } \\
\text { profiles and its market impact. It also has recently } \\
\text { conducted joint on-site inspections with other } \\
\text { supervisors to address specific issues. } \\
\text { However, the frequency of regular on-site } \\
\text { inspection for the medium- and low- impact } \\
\text { insurers should be increased. While resources } \\
\text { allocation should be prioritized according to }\end{array}$ \\
\hline
\end{tabular}




\begin{tabular}{|c|c|c|}
\hline ICP & Grading & Comments \\
\hline & & $\begin{array}{l}\text { assessed risks, the chance of detecting emerging } \\
\text { difficulties would be importantly increased if at least } \\
\text { brief inspection visits were conducted every three } \\
\text { or four years for medium-sized insurers. }\end{array}$ \\
\hline $\begin{array}{l}\text { 14. Preventive and corrective } \\
\text { measures. }\end{array}$ & $\mathrm{O}$ & $\begin{array}{l}\text { In line with the EU directives, BaFin is empowered } \\
\text { to take a range of preventative measures, which } \\
\text { allows a progressive escalation of supervisory } \\
\text { actions to respond to emerging concerns. The } \\
\text { implementation of Solvency II will imply further } \\
\text { increase of flexibility in the possible supervisory } \\
\text { actions by introducing a more specific intervention } \\
\text { ladder based on the solvency ratios. }\end{array}$ \\
\hline 15. Enforcement or sanction. & $\mathrm{O}$ & $\begin{array}{l}\text { BaFin takes a proportionate approach in exercising } \\
\text { its enforcement powers under the VAG. The use of } \\
\text { administrative fines is considered to be rarely } \\
\text { necessary due to the fact that insurers in general } \\
\text { comply even with initial informal requests from the } \\
\text { authorities. }\end{array}$ \\
\hline $\begin{array}{l}\text { 16. Winding-up or exit from } \\
\text { the market. }\end{array}$ & $\mathrm{O}$ & $\begin{array}{l}\text { Legislation provides for orderly exits of insurers } \\
\text { and a high degree of protection for policyholders in } \\
\text { the event of insolvency. }\end{array}$ \\
\hline 17. Group-wide supervision. & $\mathrm{O}$ & $\begin{array}{l}\text { The German regulatory frameworks for insurance } \\
\text { groups and financial conglomerates are broadly in } \\
\text { line with EU directives. The impending } \\
\text { implementation of Solvency II will strengthen } \\
\text { BaFin's supervision of insurance groups, subject to } \\
\text { the adequacy of regulatory resources. } \\
\text { In this regard it is advisable to consider: } \\
\text { - Increasing the adequacy of resources, } \\
\text { particularly for the effective supervision of } \\
\text { international active groups/conglomerates. } \\
\text { - Developing the risk classification tool (see ICP } \\
\text { 4) to include the group-wide supervision. } \\
\text { - Harmonizing the supervisory approach in the } \\
\text { area of group capital adequacy calculation by } \\
\text { issuing more detailed rules on, inter alia, the } \\
\text { treatment of participation in credit institutions, } \\
\text { the valuation criteria to be used. }\end{array}$ \\
\hline $\begin{array}{l}\text { 18. Risk assessment and } \\
\text { management. }\end{array}$ & $\mathrm{O}$ & $\begin{array}{l}\text { The VAG has established high-level requirements } \\
\text { relating to insurers' risk management, } \\
\text { supplemented by BaFin circular and supervisory } \\
\text { expectation. The effectiveness of insurers' risk } \\
\text { management system is assessed by BaFin under } \\
\text { its supervisory review process. The risk } \\
\text { management requirements can be seen as an } \\
\text { anticipation of Solvency II which will come into } \\
\text { force in } 2013 \text {. }\end{array}$ \\
\hline
\end{tabular}




\begin{tabular}{|c|c|c|}
\hline ICP & Grading & Comments \\
\hline 19. Insurance activity. & 0 & $\begin{array}{l}\text { BaFin directly reviews premium pricing for some } \\
\text { classes of business and monitors insurance risks } \\
\text { through its assessment of insurers' risk } \\
\text { management system and technical provisions. }\end{array}$ \\
\hline 20. Liabilities. & 0 & $\begin{array}{l}\text { There are clear, legal principles and regulatory } \\
\text { guidelines for insurers to estimate their insurance } \\
\text { liabilities. In addition, the audit reports of external } \\
\text { auditors as well as appointed actuaries for certain } \\
\text { line of businesses can also be used. BaFin } \\
\text { monitors insurers' technical provisions by off-site } \\
\text { examinations as well as on on-site inspections, and } \\
\text { has the power to require insurers to remedy any } \\
\text { shortfall. It is recommended that, in view of the } \\
\text { increasing complexity of the valuation criteria to be } \\
\text { used under Solvency II as well as their differences } \\
\text { with the current ones, BaFin should increase the } \\
\text { number of its staff equipped with actuarial } \\
\text { expertise and related quantitative skills. Its current } \\
\text { advisory role in this field could be enhanced. }\end{array}$ \\
\hline 21. Investments. & $\mathrm{O}$ & $\begin{array}{l}\text { Regulatory requirements are in place for insurers } \\
\text { to manage their investment risks in a manner } \\
\text { proportionate to the nature, scale and complexity of } \\
\text { their operations. In addition, a number of specific } \\
\text { quantitative limits are applicable on the investment } \\
\text { activity of the primary insurer in order to ensure an } \\
\text { adequate spread of the risks. } \\
\text { For the reinsurance activity, the regulation follows } \\
\text { the "prudent person principle." In view of the } \\
\text { increasing complexity of the valuation criteria to be } \\
\text { used under Solvency II, it is advisable to keep the } \\
\text { supervisory reporting requirements under review } \\
\text { and to continue developing BaFin's internal } \\
\text { assessment and monitoring. }\end{array}$ \\
\hline $\begin{array}{l}\text { 22. Derivatives and similar } \\
\text { commitments. }\end{array}$ & LO & $\begin{array}{l}\text { The regulatory policy and requirements for the use } \\
\text { of derivatives by primary insurers are aligned with } \\
\text { international best practice. Quarterly reporting is } \\
\text { also defined. } \\
\text { However, the provisions for reinsurance activity are } \\
\text { more general and the reporting requirements are } \\
\text { less stringent. }\end{array}$ \\
\hline $\begin{array}{l}\text { 23. Capital adequacy and } \\
\text { solvency. }\end{array}$ & 0 & $\begin{array}{l}\text { The capital adequacy regime is based on the EU } \\
\text { directives (Solvency I). The implementation of } \\
\text { Solvency II with effect from January } 2013 \text { will result } \\
\text { in a more risk-sensitive regime that will enhance } \\
\text { risk-based supervision. }\end{array}$ \\
\hline 24. Intermediaries. & LO & $\begin{array}{l}\text { BaFin is not responsible for the direct supervision } \\
\text { of the intermediaries. The implementation of the } \\
\text { relevant EU directive has been a major step in }\end{array}$ \\
\hline
\end{tabular}




\begin{tabular}{|c|c|c|}
\hline ICP & Grading & Comments \\
\hline & & $\begin{array}{l}\text { enhancing the supervision of intermediaries, but it } \\
\text { is difficult to assess the effectiveness of market } \\
\text { conduct control performed by the competent } \\
\text { supervisors. It is advisable to carry out such an } \\
\text { analysis and take appropriate actions to continue } \\
\text { improving the protection of policyholders at the } \\
\text { point of sale. }\end{array}$ \\
\hline 25. Consumer Protection. & $\mathrm{O}$ & $\begin{array}{l}\text { There are various tools which enable the } \\
\text { consumers to solve possible issues ranging from } \\
\text { the complaints to BaFin, the help of consumers' } \\
\text { associations and the ombudsman. }\end{array}$ \\
\hline $\begin{array}{l}\text { 26. Information, disclosure } \\
\text { and transparency } \\
\text { towards markets. }\end{array}$ & $\mathrm{O}$ & $\begin{array}{l}\text { There is room for improvement in the BaFin } \\
\text { publications of market data and analysis, including } \\
\text { key data of individual insurers and the timeliness of } \\
\text { publication. Moreover, in view of the incoming } \\
\text { Solvency II regime, consideration should be given } \\
\text { to the enhancement of the disclosure requirements } \\
\text { applied to the insurers. }\end{array}$ \\
\hline 27. Fraud. & $\mathrm{O}$ & The core requirements are in place. \\
\hline $\begin{array}{l}\text { 28. Anti-money-laundering, } \\
\text { combating the financing } \\
\text { of terrorism (AML/CFT). }\end{array}$ & LO & $\begin{array}{l}\text { While BaFin is in the process of addressing the } \\
\text { weaknesses identified in the FATF, especially } \\
\text { when dealing with the increased control of the } \\
\text { insurers' activity, there is no evidence that remedial } \\
\text { actions are systematically taken by the Länder with } \\
\text { regard to insurance intermediaries that they } \\
\text { supervise. }\end{array}$ \\
\hline
\end{tabular}

\begin{tabular}{|l|l|}
\hline Observed (O) & 23 \\
\hline Largely observed (LO) & 5 \\
\hline Partly observed (PO) & 0 \\
\hline Not Observed (NO) & 0 \\
\hline Total & $\mathbf{2 8}$ \\
\hline
\end{tabular}

\section{Recommended Action Plan And Authorities' Response}

\section{A. Recommended Action Plan}

\section{The following recommendations aim to suggest measures to further improve}

insurance regulations and supervision. In many areas they go beyond the essential criteria of the ICPs. 
Table 2. Germany: Recommendations to Improve Observance of ICPs

\begin{tabular}{|c|c|}
\hline ICP & Recommendation \\
\hline 3. Supervisory authority. & $\begin{array}{l}\text { There is scope for strengthening regulatory resources, particularly for } \\
\text { supervision of internationally active insurance groups and } \\
\text { implementation of Solvency II. Public disclosure of the reasons for } \\
\text { removal of board members should be envisaged. }\end{array}$ \\
\hline 4. Supervisory process. & $\begin{array}{l}\text { It is recommended that BaFin continue to develop a risk-based } \\
\text { supervisory approach, by further enlarging the risk model which has } \\
\text { been put in place to also take into account the group-wide supervision. } \\
\text { As stress testing and other quantitative supervisory techniques are } \\
\text { developed, they should strongly influence prioritization in the } \\
\text { supervisory process. }\end{array}$ \\
\hline 7. Suitability of persons. & $\begin{array}{l}\text { Consideration should be given to having the power to extend similar } \\
\text { requirements, as needed, to other high level managers who determine } \\
\text { day-to-day policies. Moreover, it is recommended that insurers be } \\
\text { required to report to BaFin as they become aware of circumstances } \\
\text { that may be relevant for the fitness and propriety of key functionaries. }\end{array}$ \\
\hline 9. Corporate governance. & $\begin{array}{l}\text { It will be important to continue to check that mutual insurers do in fact } \\
\text { follow procedures equivalent to the corporate governance code (from } \\
\text { which they are exempt), and adapt those procedures as needed as } \\
\text { Solvency II is introduced. }\end{array}$ \\
\hline 11. Market analysis. & $\begin{array}{l}\text { BaFin should continue to develop stress testing capacity, especially } \\
\text { regarding larger insurers and financial groups, and longer-term effects. }\end{array}$ \\
\hline 12. Reporting to supervisors. & $\begin{array}{l}\text { It is advisable to introduce an explicit obligation for the prompt } \\
\text { notification of supervisors by insurers and auditors of any material } \\
\text { changes which affect the current or foreseeable financial condition of } \\
\text { an institution. } \\
\text { Care should continue to be taken to keep reporting requirements up to } \\
\text { date, while containing regulatory burden, for example, by harmonizing } \\
\text { and centralizing to the extent possible reporting requirements imposed } \\
\text { by authorities in different jurisdictions or for different purposes. }\end{array}$ \\
\hline 13. On-site inspection. & $\begin{array}{l}\text { It is recommended that, without sacrificing the principles of risk based } \\
\text { supervision, the frequency of regular on-site inspection for the medium } \\
\text { and the low impact insurers be increased to bring it closer to } \\
\text { international best practice. }\end{array}$ \\
\hline $\begin{array}{l}\text { 14. Preventive and corrective } \\
\text { measures. }\end{array}$ & $\begin{array}{l}\text { The level of sanctions will need to be kept under review to ensure that } \\
\text { they remain effective as deterrents. }\end{array}$ \\
\hline 17. Group-wide supervision. & $\begin{array}{l}\text { It is advisable to consider: } \\
\text { - Increasing the adequacy of resources, particularly for the effective } \\
\text { supervision of international active groups and financial } \\
\text { conglomerates. } \\
\text { - Developing the risk classification tool (see ICP 4) to include the } \\
\text { group-wide supervision. } \\
\text { Harmonizing the supervisory approach in the area of group capital } \\
\text { adequacy calculation by issuing more detailed rules on, inter alia, } \\
\text { the treatment of participation in credit institutions, the valuation } \\
\text { criteria to be used. }\end{array}$ \\
\hline
\end{tabular}




\begin{tabular}{|c|c|}
\hline ICP & Recommendation \\
\hline & - Regularly addressing group-wide effects in stress tests. \\
\hline 20. Liabilities. & $\begin{array}{l}\text { It is recommended that, in view of the increasing complexity of the } \\
\text { valuation criteria to be used under Solvency II as well as their } \\
\text { differences with the current ones, BaFin should increase the number of } \\
\text { its staff equipped with actuarial expertise and related quantitative skills. } \\
\text { Its advisory function in this field could be enhanced. } \\
\text { Stress tests for liability-side risks should be refined and conducted } \\
\text { more frequently to assess the sensitivity of results to variations in } \\
\text { actuarial assumptions and discount rates. }\end{array}$ \\
\hline 21. Investments. & $\begin{array}{l}\text { In view of the increasing complexity of the valuation criteria to be used } \\
\text { under Solvency II, it is advisable to keep the supervisory reporting } \\
\text { requirement under review, and to continue developing BaFin's internal } \\
\text { assessment and monitoring. }\end{array}$ \\
\hline $\begin{array}{l}\text { 22. Derivatives and similar } \\
\text { commitments. }\end{array}$ & $\begin{array}{l}\text { It is recommended that the "prudent person principle" approach which } \\
\text { forms the basis for the supervision of reinsurers' investment activity } \\
\text { and use of derivatives be complemented by reinforced off-site and on- } \\
\text { site monitoring of such activities. }\end{array}$ \\
\hline 24. Intermediaries. & $\begin{array}{l}\text { It is advisable to carry out an analysis of the impact of the relevant EU } \\
\text { directive, and take appropriate actions to continue improving the } \\
\text { protection of policyholders at the point of sale. }\end{array}$ \\
\hline $\begin{array}{l}\text { 26. Information, disclosure } \\
\text { and transparency } \\
\text { towards markets. }\end{array}$ & $\begin{array}{l}\text { Time lags in the publication of aggregate insurance data should be } \\
\text { shortened. The availability of preliminary data-perhaps when over } \\
90 \text { percent of input data have been compiled—on a more timely basis } \\
\text { would be valuable. }\end{array}$ \\
\hline 28. AML/CFT. & $\begin{array}{l}\text { The authorities should continue to address the weaknesses identified } \\
\text { through the FATF Mutual Evaluation as quickly as reasonably possible. }\end{array}$ \\
\hline
\end{tabular}

\section{B. Authorities' Response to the Assessment}

18. The authorities broadly agree with the assessment.

\section{Detailed ASSESSMent}

\section{Table 3. Detailed Assessment of Observance of the Insurance Core Principles}

\begin{tabular}{|c|c|}
\hline \multicolumn{2}{|c|}{ Conditions for Effective Insurance Supervision } \\
\hline Principle 1. & $\begin{array}{l}\text { Conditions for effective insurance supervision } \\
\text { Insurance supervision relies upon: } \\
\text { - a policy, institutional, and legal framework for financial sector supervision; } \\
\text { - a well-developed and effective financial market infrastructure; and } \\
\text { - efficient financial markets. }\end{array}$ \\
\hline Description & $\begin{array}{l}\text { The Federal Ministry of Finance bears the political responsibility for the proper } \\
\text { functioning of the German insurance system. } \\
\text { BaFin's highest priority is to seek to discharge its statutory mandate to the very } \\
\text { best of its ability. In discharging its duties, it cooperates closely with the }\end{array}$ \\
\hline
\end{tabular}


supervisory authorities of the other EU member states and takes due account of the objectives of a harmonized European supervisory practice and financial market stability in other European member states.

The supervision of insurance companies in Germany is based on German insurance law, ordinances, codes, and circulars. The legal requirements governing insurance companies originate in particular, in company law, commercial law, and insurance law.

The principal legislation for the supervision of insurance is the VAG.

The German legal system is almost entirely based on codifications. All laws are publicly available for sale or free of charge on the internet. Ordinances, circulars, recommendations, and other guidance papers reflecting the current administrative practice are available on BaFin's website or upon request. BaFin's involvement in issuing such laws and ordinances is limited to an advisory function. Ordinances may be issued by BaFin in exceptional cases when the authorization to do so is transferred to it by the federal ministry, which, under the law, is responsible for the matter in question and has been authorized by law to transfer such authorization.

Germany has a well developed, reliable, effective, and efficient legal and court system, with specialized branches whose decisions are enforceable. Most of the decisions taken by BaFin are addressed as administrative acts, which need preliminary proceedings before a claim can be brought before an administrative court. This gives the chance to check the legitimacy of the decision.

Judges and lawyers are professionals with a background of two state examinations. Judges have a legal status similar to civil servants, one of the specific distinctions being that their independence is guaranteed by law. Honorary judges only work in teams with professional judges. Alternative dispute mechanisms are used to conciliate insurance and banking disputes. Special procedures for an ombudsman with an appropriate legal framework have been established.

The German accounting principles are laid down in the Commercial Code. In addition, the Institute of German Certified Public Accountants and the German Accounting Standards Committee issue statements on accounting questions. Although these statements are not legally binding, companies and their auditors generally observe them.

German public accountants and sworn accountants, as well as statutory auditors and sworn accountant firms, have to (a) be members of the chamber of accountants; (b) be independent; and (c) comply with numerous rules, which also comprise ethical standards, to be found in particular in the professional statutes for certified and sworn accountants.

Concerning the fit and proper requirements for auditors, BaFin relies on the professional bodies, especially the chamber of accountants. Nevertheless, the appointment of an auditor has to be notified and BaFin may, if it has objections, deny the approval of the appointment.

The German Actuary Association issues rules for its members in order to ensure a high quality standard of actuarial work and the observance of ethical standards. The actuary must have the qualifications, which prove that he is fit and proper. The actuary must be as independent and un-influenced as possible. 


\begin{tabular}{|c|c|}
\hline & $\begin{array}{l}\text { Basic economic, financial, and social statistics are publicly available. BaFin } \\
\text { publishes a special report concerning statistics in the field of supervised insurance } \\
\text { undertakings annually. } \\
\text { Germany has a well-functioning money and securities markets. }\end{array}$ \\
\hline Assessment & Observed. \\
\hline Comments & $\begin{array}{l}\text { Insurance supervision in Germany is facilitated by sound and progressive financial } \\
\text { sector policy framework and financial market infrastructure. }\end{array}$ \\
\hline \multicolumn{2}{|c|}{ The Supervisory System } \\
\hline Principle 2. & $\begin{array}{l}\text { Supervisory objectives } \\
\text { The principal objectives of insurance supervision are clearly defined. }\end{array}$ \\
\hline Description & $\begin{array}{l}\text { The objectives of insurance supervision, as defined in VAG, are to provide } \\
\text { adequate safeguards of the interests of policyholders and, in so doing, above all, to } \\
\text { ensure that the obligations arising under insurance and reinsurance contracts can } \\
\text { be met at all times. } \\
\text { According to its mission statement, BaFin's function is to limit risks to the German } \\
\text { financial system at both the national and international levels and to ensure that } \\
\text { Germany as a financial center, continues to function properly and that its integrity } \\
\text { is preserved. } \\
\text { BaFin discloses how the objectives are applied in its mission statement and annual } \\
\text { reports as well as by ad hoc press releases and information sessions. } \\
\text { As the objectives of insurance supervision are legally binding, there is no } \\
\text { opportunity for deviation to take place. } \\
\text { In case the application of rules demonstrates that the legal provisions contain } \\
\text { gaps, corrections may be proposed on the occasion of the next revision of the law } \\
\text { in question. Where provisions lead to misunderstandings, BaFin may issue } \\
\text { regulations or circulars which do explain, interpret, and clarify the legal text in } \\
\text { question. Conflicts of interest, which may occur in administrative decisions, are } \\
\text { solved in accordance with an appreciation of values and the exercise of legal } \\
\text { discretion. }\end{array}$ \\
\hline Assessment & Observed. \\
\hline Comments & $\begin{array}{l}\text { The objectives fixed under the law are mainly focused on the protection of the } \\
\text { policyholders. Consideration could be given to explicitly mention in VAG systemic } \\
\text { stability, in keeping with BaFin's overall mandate. }\end{array}$ \\
\hline Principle 3. & $\begin{array}{l}\text { Supervisory authority } \\
\text { The supervisory authority: } \\
\text { - has adequate powers, legal protection and financial resources to exercise its } \\
\text { functions and powers } \\
\text { - is operationally independent and accountable in the exercise of its functions } \\
\text { and powers } \\
\text { - hires, trains and maintains sufficient staff with high professional standards } \\
\text { treats confidential information appropriately. }\end{array}$ \\
\hline Descr & $\begin{array}{l}\text { Insurance supervision is divided between the federal government and the federal } \\
\text { states (länder), in accordance with the federal system of the Federal Republic of }\end{array}$ \\
\hline
\end{tabular}


Germany. The supervision of insurance entities is predominantly exercised by BaFin, which supervises on behalf of the federal government, private insurance undertakings operating in Germany, which are of material economic significance, and public insurance undertakings engaging in open competition, which operate across the borders of any federal state.

The supervisory authorities of the federal states are mainly responsible for supervising public insurers whose activities are limited to the federal state in question and those private insurance undertakings, which are of lesser economic significance (2 percent in terms of market share).

The legislation (VAG) provides for specific rules which govern the allocation of responsibilities for supervision between BaFin and the federal authorities. $\mathrm{BaFin}$ is part of the executive. The legal and supervisory control of the BMF are defined in the law and further elaborated in specific guidelines for the control of $\mathrm{BaFin}$ by the federal ministry of finance. These guidelines define a number of reporting duties BaFin has to perform, ranging from internal organizational decisions, intended supervisory measures, intended delegated supervisory legislation, circulars or announcements. More specifically, BaFin operates as a legal person in the form of an institution of public law that is functionally and organizationally separate from the federal ministry of finance. However, the German constitution (Grundgesetz) requires that decisions by the executive branch must not be taken by bodies outside of parliamentary control. For BaFin, this control is guaranteed via the legal and supervisory control (rechts- und fachaufsicht) by the federal ministry of finance, which in turn is controlled by the German parliament (section 2 of the act establishing BaFin (FinDAG) and guidelines for the control of BaFin by the federal ministry of finance).

BaFin is operationally independent. The oversight role of the federal ministry of finance has an ex post character, there are no provisions for an ex ante involvement in individual supervisory decisions and/or actions. In practice, there is no evidence of the federal ministry of finance influencing day-to-day supervisory decisions of BaFin. Also, there is no evidence of government or industry interference in BaFin's supervisory tasks.

The supervisory authority has the power, in relation to undertakings, members of their management board, or persons controlling such undertakings, to issue any orders that may be appropriate and necessary in order to prevent or remedy any irregularities. In the event of noncompliance, the supervisory authority has various enforcement measures at its disposal such as to appoint a special commissioner, to revoke an undertaking's license, or to conduct ad hoc surveys.

The administrative bodies of BaFin consist of the president, the executive board (of which the president is part of) and the administrative council. The executive board manages and governs BaFin. The executive board consists of the president and four chief executive directors of whom one is vice-president. The administrative council, which consists of members from different federal ministries, members from the German Federal Parliament, and representatives from the financial services sectors, has the task to monitor BaFin's management and to support BaFin in the execution of its duties. BaFin's president is required to report regularly to the administrative council on the conduct of his management activities.

An insurance advisory council composed of insurance experts assists BaFin in the field of insurance supervision. An internal audit and a data protection office, which reports directly to the president, are in place. 
There are explicit procedures regarding the appointment and dismissal of the head and the members of the governing body in place. The Civil Service Act (BBG) sets out the criteria for the dismissal of civil servants, which include health problems, inability to fulfill the duties of the position, or criminal behavior. In case of his dismissal, a civil servant can make an appeal to the administrative court. In addition, most of the staff, and especially the senior staff, are civil servants and conform to high ethical standards, including those relating to confidentiality. Public disclosure of the reasons for dismissal is not required.

BaFin staff is subject to a code of conduct for public employees as well as to some more specific provisions to prevent corruption, which takes into account the special circumstances of the supervisor, e.g., their relations with the supervised institution and shall avoid the appearance of conflicts of interests.

BaFin is entirely financed by levies and fees paid by the undertakings supervised. BaFin receives no funding from the federal budget. Pursuant to section 13 (1) FinDAG, BaFin's sources of funding consist primarily of: fees (section 14 FinDAG); separate reimbursements (section 15 FinDAG); and contributions (section 16 FinDAG). The actual amount of fees and contributions is calculated on the basis of the ordinance on the imposition of fees and allocation of costs pursuant to the FinDAG (FinDAGKostV) and in accordance with special rules governing the charges to be applied by BaFin.

A public consultation takes place before issuing a new regulation.

In most cases objections against measures of BaFin do not have any suspensory effect.

BaFin publishes its budget plan, which is audited by the German Federal Court of Auditors and by an external auditor.

At end-2010, BaFin employed 257 staff in its insurance and pension fund supervision department, compared to 215 at end-2009, 186 at end-2004, and 70 at end-2002. In addition, at end-2010 BaFin employed 35 staff on cross-sectoral modeling, 62 on the integrity of the financial system, and 87 on the prevention of money laundering.

BaFin attaches importance to the basic and advanced training of its staff. By means of various targeted training syllabuses, BaFin trains its junior staff itself inhouse. It thus has qualified and committed staff at its disposal for any duties that may come its way in future, as well. In addition, in-house training courses and taking part in external training courses ensure continuing, needs-based training for all members of staff.

BaFin selects its staff through interviews and assessments centers. In order to promote skills, BaFin offers various in-house and external training opportunities.

Personnel and organizational development opportunities pursue similar goals: personnel development equips each member of staff with the skills required to perform his duties successfully; organizational development deals with the structure and process of the organization and the appropriate structuring of teams, sections, and departments.

In 2009, 1,145 members of staff took part in professional development courses. 


\begin{tabular}{|c|c|}
\hline & $\begin{array}{l}\text { This corresponds to } 71 \text { percent of all employees }(1,829) \text {. In } 2009 \text {, a total of } 470 \\
\text { training events were held. Each employee participated in an average of } 4 \text { days of } \\
\text { professional development in } 2009 \text {. } \\
\text { If a person in the exercise of a public office is in breach of his official obligations, } \\
\text { liability rests, in principle, with the state or the public body which employs this } \\
\text { person. If the official is guilty of willful intent or gross negligence, the public body } \\
\text { has right of recourse. BaFin's liability is limited because BaFin performs its } \\
\text { functions and exercises its powers exclusively in the public's interest. }\end{array}$ \\
\hline Assessment & Largely Observed. \\
\hline Comments & $\begin{array}{l}\text { BaFin is operationally independent and subject to clear accountability mechanisms; } \\
\text { its staff is experienced and qualified. Public disclosure of the reasons for dismissal } \\
\text { of board members should be required, although it is recognized that in practice } \\
\text { reasons would be given. It is recommended, moreover, that the guidance for the } \\
\text { control of BaFin by the federal ministry of finance be reviewed to reduce the } \\
\text { reporting burden and grant more operational autonomy to the supervisor. There is } \\
\text { also scope for strengthening regulatory resources, particularly for supervision of } \\
\text { internationally active insurance groups and implementation of Solvency II. } \\
\text { Notwithstanding BaFin's operational independence and accountability, the } \\
\text { reporting requirements currently laid down in the guidelines for the control of BaFin } \\
\text { by the federal ministry of finance place a large burden both on BaFin and on the } \\
\text { federal ministry of finance. The German authorities may wish to reassess whether } \\
\text { the reporting requirements can be reduced without hampering the federal ministry } \\
\text { of finance in overseeing the legality and fitness for purpose of BaFin's } \\
\text { administrative actions. }\end{array}$ \\
\hline Principle 4. & $\begin{array}{l}\text { Supervisory process } \\
\text { The supervisory authority conducts its functions in a transparent and accountable } \\
\text { manner. }\end{array}$ \\
\hline Description & $\begin{array}{l}\text { BaFin publishes its supervisory processes and policy requirements in essential } \\
\text { areas by way of circulars, guidelines, and announcements. All the relevant } \\
\text { documents are made available to the general public on BaFin's website. } \\
\text { Proactive disclosure on the part of BaFin is in the process of being intensified. The } \\
\text { Solvency II project has so far, and will in the future, contribute toward even more } \\
\text { transparency. } \\
\text { The intensity of supervision depends on how high the competent supervisor judges } \\
\text { the risk that an insurer might not, or not fully, comply with the applicable legal, } \\
\text { regulatory and supervisory requirements. BaFin allocates the insurance } \\
\text { undertakings in different risk classes depending on some key performance } \\
\text { indicators which are automatically calculated and further refined by the line } \\
\text { supervisors which have further qualitative information. The risk classification also } \\
\text { takes into account the market impact of the insurers (low, medium, high). Risk } \\
\text { profiles for insurers will be further refined with the implementation of the Solvency II } \\
\text { regime. } \\
\text { In order to ensure that legal actions do not impede the ability to make timely } \\
\text { interventions, BaFin can immediately issue enforceable administrative acts and } \\
\text { objections, which do not have suspensory effects. } \\
\text { BaFin annually publishes information about the state of affairs of the insurance } \\
\text { undertakings subject to its supervision and its observations with respect to the }\end{array}$ \\
\hline
\end{tabular}




\begin{tabular}{|c|c|}
\hline & $\begin{array}{l}\text { insurance sector. It also regularly publishes its legal and administrative principles. } \\
\text { The process to appeal supervisory decisions is specified under the Code of } \\
\text { Administrative Court Procedures. }\end{array}$ \\
\hline Assessment & Observed. \\
\hline Comments & $\begin{array}{l}\text { BaFin is moving toward a more risk-based supervisory approach, which will be fully } \\
\text { in place once Solvency II is implemented. For the time being a risk model to select } \\
\text { and prioritize the supervisory analysis has been made operational. It is } \\
\text { recommended that it is further developed to better take into account the } \\
\text { supervision of insurance groups. } \\
\text { As stress testing and other quantitative supervisory techniques are developed, they } \\
\text { should strongly influence prioritization in the supervisory process. }\end{array}$ \\
\hline Principle 5. & Supervisory cooperation and information sharing \\
\hline & $\begin{array}{l}\text { The supervisory authority cooperates and shares information with other relevant } \\
\text { supervisors subject to confidentiality requirements. }\end{array}$ \\
\hline Description & $\begin{array}{l}\text { BaFin is empowered to share confidential information with other supervisors, even } \\
\text { if there is no formal agreement in place, provided that they are subject to } \\
\text { equivalent professional secrecy obligation. } \\
\text { Confidential information comprises, in particular, business and industrial secrets of } \\
\text { the primary insurers and reinsurers as well as of the insured. It also includes any } \\
\text { information that has been provided on condition that it is kept confidential. Breach } \\
\text { of secrecy is penalized. However, it is permissible, for example, to pass on } \\
\text { confidential information to authorities responsible for insurance, banking, stock } \\
\text { market, and securities supervision and to central banks, if these authorities need } \\
\text { the information in order to carry out their tasks. } \\
\text { BaFin, beyond being signatory of the EU/ EEA Protocols regarding the cooperation } \\
\text { between supervisory authorities, underpinned by EU directives, has signed a } \\
\text { number of bilateral MoUs with Australia, China, Dubai, some states of the United } \\
\text { States, and has also signed the IAIS multilateral MoU (MMoU) on cooperation and } \\
\text { information exchange. } \\
\text { The types of confidential information which can be exchanged need to meet certain } \\
\text { preconditions, in particular the information is needed for supervisory purpose and } \\
\text { its confidentiality is protected. The recipient authority is allowed to pass on to third } \\
\text { parties information it receives from BaFin only to the extent that BaFin itself would } \\
\text { be allowed to provide such information to the third parties in question. } \\
\text { In case of doubts, BaFin may ask for the consensus of the undertaking concerned } \\
\text { to pass the information to other supervisory authorities. } \\
\text { Before taking supervisory actions that affect the supervisory duties of the } \\
\text { supervisor(s) of another EU state, BaFin consults the relevant supervisor(s) or } \\
\text { seek advice from the lead supervisor. BaFin is obliged to provide adequate } \\
\text { information to facilitate supervision of financial groups or conglomerates by } \\
\text { relevant supervisors in EU states. } \\
\text { When a non-EU/EEA member state is involved, a further criterion needs to be } \\
\text { considered, namely whether the information will be used in that country only for the } \\
\text { purposes for which it is intended. }\end{array}$ \\
\hline Assessment & Observed. \\
\hline
\end{tabular}




\begin{tabular}{|c|c|}
\hline Comments & $\begin{array}{l}\text { It is recommended that the concrete application of the confidentiality rules be } \\
\text { monitored in order to avoid that it become an obstacle for full information sharing } \\
\text { among supervisors. }\end{array}$ \\
\hline \multicolumn{2}{|c|}{ The Supervised Entity } \\
\hline Principle 6. & $\begin{array}{l}\text { Licensing } \\
\text { An insurer must be licensed before it can operate within a jurisdiction. The } \\
\text { requirements for licensing are clear, objective and public. }\end{array}$ \\
\hline Description & 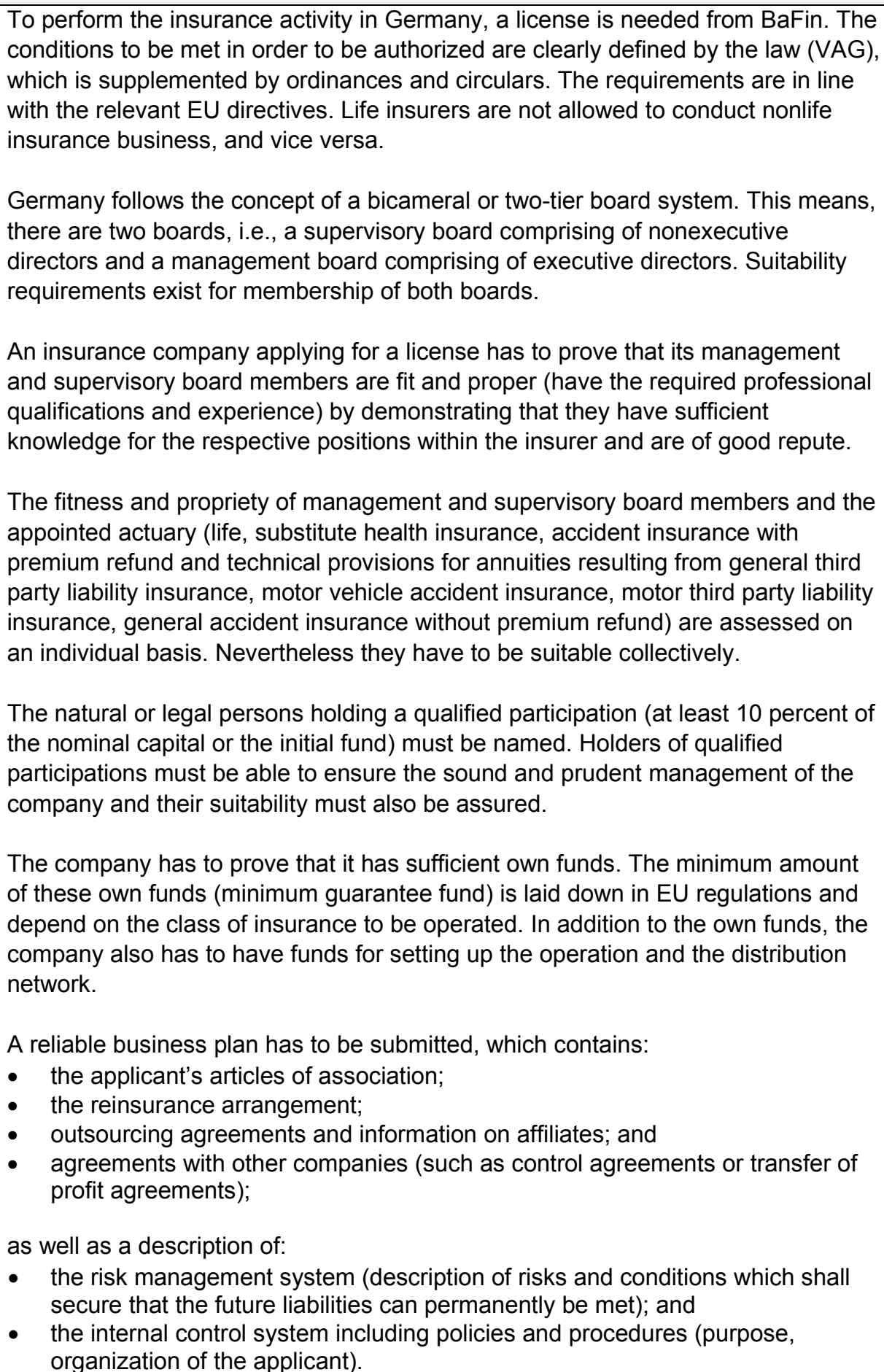 \\
\hline
\end{tabular}




\begin{tabular}{|c|c|}
\hline & 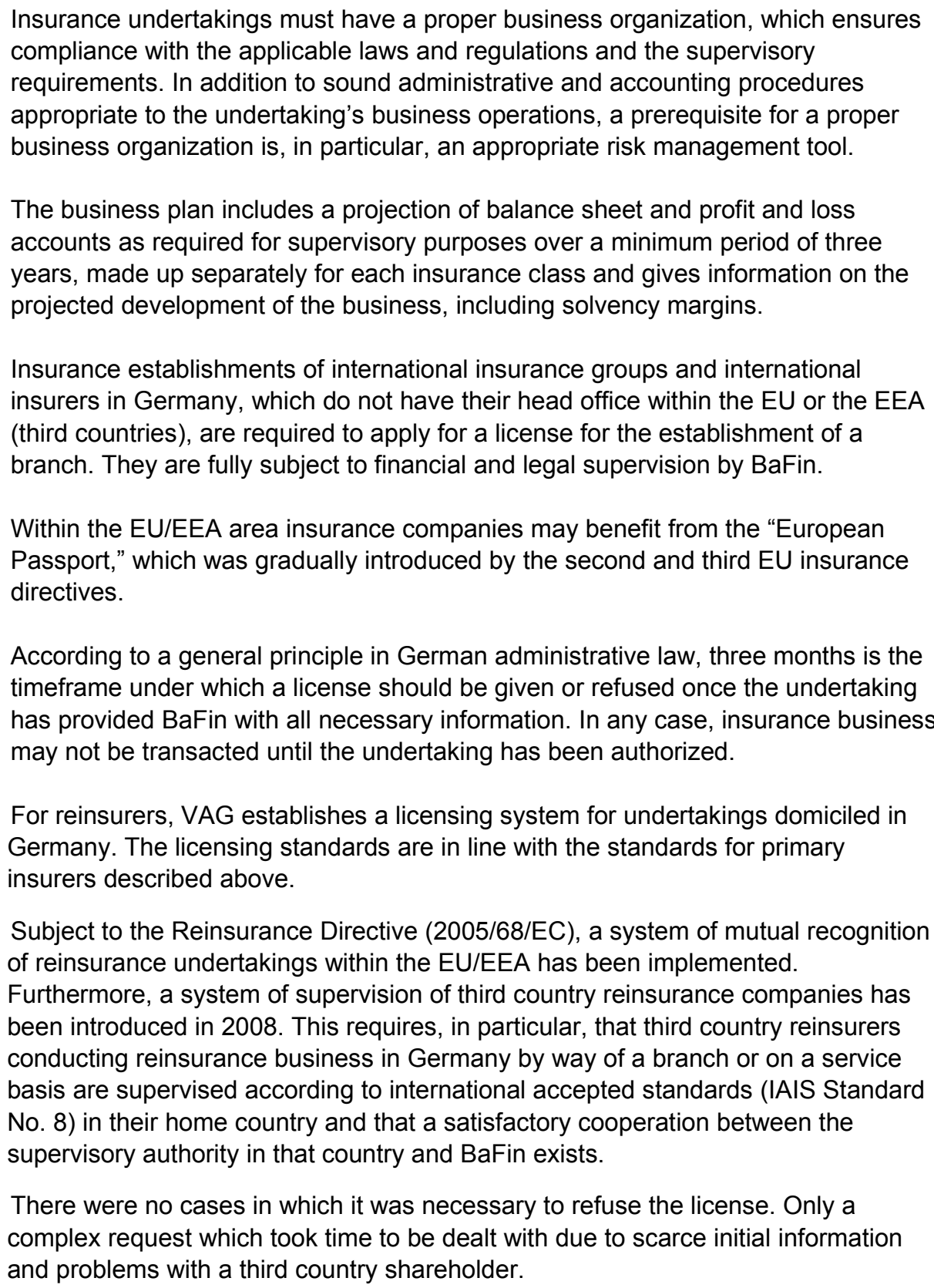 \\
\hline Assessment & Observed. \\
\hline Comments & $\begin{array}{l}\text { The licensing regime for insurers, which is based on EU Directives, is clear and } \\
\text { transparent. }\end{array}$ \\
\hline Principle 7. & $\begin{array}{l}\text { Suitability of persons } \\
\text { The significant owners, board members, senior management, auditors and } \\
\text { actuaries of an insurer are fit and proper to fulfill their roles. This requires that they } \\
\text { possess the appropriate integrity, competency, experience and qualifications. }\end{array}$ \\
\hline Description & $\begin{array}{l}\text { Suitability requirements exist for members of both the supervisory board and the } \\
\text { management board, as well as for holders of qualified participations in insurance } \\
\text { undertakings and for appointed actuaries, where required. }\end{array}$ \\
\hline
\end{tabular}


The members of the management board must be reliable and qualified. To meet the qualification requirement, the manager must dispose of sufficient theoretical and practical knowledge relating to insurance business, as well as management experience. Members of the supervisory board must have sufficient experience to fulfill their task within the insurer taking due regard to the nature, scale, and complexity of the insurer.

They must also be of good repute, which means that their background is screened to check any financial problems or bankruptcy; any civil liability as a consequence of unpaid debts; any convictions in criminal cases; any outcome of previous assessments of suitability, or sanctions or disciplinary actions taken by another supervisor.

Conflicts of interests rules are defined in relation to the maximum number of mandates (e.g., two for managing board and five for supervisory board, except within the same group; BaFin may grant exceptions), the composition of the management and supervisory boards and cooling-off periods.

The holders of a qualified participating interest in the insurance undertaking must meet the demands required in the interest of ensuring sound and prudent management of the insurance undertaking, in particular the requirement of reliability.

Any shortcomings may result in the refusal, restriction, or withdrawal of the license or the dismissal of a member of either the management or supervisory boards.

In this regard, BaFin usually consults the Federal Central Register of previous convictions and the Federal Central Register of Trade and Industrial Offences.

To the extent that there is evidence to suggest that the holder of a qualified participating interest does not meet the requirements, or that the affiliation with other persons or companies would hinder effective supervision of the insurer, due to the ownership structure or poor economic transparency, BaFin may impose predefined measures. BaFin may prohibit the holder of a qualified participating interest, as well as the undertakings controlled by it, from exercising its voting rights and stipulate that disposition of the shares is subject to the approval of BaFin.

The name of the designated appointed actuary must be submitted to BaFin, together with the information necessary to assess reliability and qualification. If there is evidence that the designated appointed actuary does not meet the requirements for reliability or qualification, $\mathrm{BaFin}$ may require that another person be appointed. If, after the appointment, there should be evidence of circumstances which would have prevented appointment, or if the appointed actuary does not properly fulfill its duties, BaFin may require that another appointed actuary be appointed.

Auditors have to be a member of the chamber of accountants and have to comply with numerous rules, which include ethical standards. The appointment of an auditor has to be notified and BaFin may, if it has any objections, deny its approval for appointment.

Trustees in life insurance (section 11b VAG): To the extent that the premiums of life insurance contracts concluded after 28 July 1994 may be changed with effect for existing contracts, any such changes may only be implemented after approval 


\begin{tabular}{|c|c|}
\hline & $\begin{array}{l}\text { by an independent trustee. } \\
\text { Changes to health insurance premiums: trustees (section 12b VAG): Only persons } \\
\text { who are reliable and qualified and not affiliated with the insurance undertaking and } \\
\text { who, in particular, have not concluded an employment contract or other service } \\
\text { contract with the insurance undertaking or any affiliated undertaking, and have no } \\
\text { claims against the undertaking under such a contract, may be appointed as } \\
\text { trustee. To meet the qualification requirement, the trustee shall dispose of sufficient } \\
\text { knowledge in the field of premium calculation in health insurance. } \\
\text { Should an insurer become aware of circumstances that may be relevant for the } \\
\text { suitability of the relevant individuals, it has to immediately take appropriate } \\
\text { measures to remedy the situation in order to comply with the principle of good and } \\
\text { sound business practices. There is not a specific and immediate obligation to notify } \\
\text { such problems to the supervisor. }\end{array}$ \\
\hline Assessment & Largely Observed. \\
\hline Comments & $\begin{array}{l}\text { BaFin performs robust due diligence on any proposed significant owner, board } \\
\text { members, trustees, and appointed actuaries prior to licensing and after by also } \\
\text { monitoring subsequent changes. } \\
\text { Consideration should be given to having the power to extend similar requirements, } \\
\text { as needed, to other high level managers who determine day-to-day policies. } \\
\text { Moreover, it is suggested that insurers be required to report to BaFin as they } \\
\text { become aware of circumstances that may be relevant for the fitness and propriety } \\
\text { of key functionaries. }\end{array}$ \\
\hline Principle 8. & $\begin{array}{l}\text { Changes in control and portfolio transfers } \\
\text { The supervisory authority approves or rejects proposals to acquire significant } \\
\text { ownership or any other interest in an insurer that results in that person, directly or } \\
\text { indirectly, alone or with an associate, exercising control over the insurer. } \\
\text { The supervisory authority approves the portfolio transfer or merger of insurance } \\
\text { business. }\end{array}$ \\
\hline Description & $\begin{array}{l}\text { Any person wishing to own, acquire, or increase a qualifying holding in a German } \\
\text { insurer needs to be authorized by BaFin. A qualified participation is deemed to } \\
\text { exist if either directly or indirectly through one or several subsidiaries or a similar } \\
\text { relationship or through collaboration with other persons or undertakings at least } \\
10 \text { percent of the nominal capital or voting rights of an insurance undertaking are } \\
\text { held, or of the members funds of a mutual society have been subscribed, or if } \\
\text { even, though this percentage is not reached, a decisive influence can be exercised } \\
\text { on the management of the insurer. } \\
\text { Furthermore, the insurance company as well as the acquiring party has to notify } \\
\text { BaFin when a threshold of } 20 \text { percent, } 30 \text { percent or } 50 \text { percent is reached or when } \\
\text { a qualified participation of a minimum of } 10 \text { percent is reached. } \\
\text { Insurance companies are required to notify BaFin of any pending transactions that } \\
\text { would result in a qualified participation as soon as they become aware of that. } \\
\text { Any intended acquisition of or the increase in a qualified participation has to be } \\
\text { notified in advance to BaFin, which is given at least } 60 \text { working days to assess the } \\
\text { acquisition. }\end{array}$ \\
\hline
\end{tabular}




\begin{tabular}{|c|c|}
\hline & $\begin{array}{l}\text { The relevant documentation is defined and BaFin may ask for further info, including } \\
\text { the ones to assess the transparency of ownership structure. } \\
\text { BaFin may prohibit the intended transaction if the acquisition might jeopardize the } \\
\text { sound and prudent operations of the insurer, or result in a control structure that } \\
\text { impedes effective supervision. There are no recent cases where a transaction had } \\
\text { to be prohibited. } \\
\text { Any transfer of insurance contracts' portfolio has to be approved by the supervisor. } \\
\text { The transferee undertaking must prove that all the requirements are met even after } \\
\text { the transfer (solvency margin, coverage of technical provisions). Otherwise, the } \\
\text { transfer may be refused or restricted. } \\
\text { Special attention is dedicated to ensure that the transaction (both acquisition and } \\
\text { portfolio transfer) does not entail any disadvantage for the policyholders, especially } \\
\text { in the life sector due to the mechanism for the recognition of profit and bonuses. }\end{array}$ \\
\hline Assessment & Observed \\
\hline Comments & $\begin{array}{l}\text { The conditions under which a qualified holding in an insurance undertaking can be } \\
\text { assumed are clear and in line with the relevant EU directives. Portfolio transfers } \\
\text { must be approved by BaFin. }\end{array}$ \\
\hline Principle 9. & $\begin{array}{l}\text { Corporate governance } \\
\text { The corporate governance framework recognizes and protects rights of all } \\
\text { interested parties. The supervisory authority requires compliance with all applicable } \\
\text { corporate governance standards. }\end{array}$ \\
\hline Description & $\begin{array}{l}\text { The roles and responsibilities of members of the management and supervisory } \\
\text { boards are defined by the law. While the supervisory board is mainly responsible } \\
\text { for the overall policies and strategies of the insurer and the oversight over the } \\
\text { management board, the management board manages the insurer on a day-to-day } \\
\text { basis (policy decisions) and keeps the supervisory board adequately informed. } \\
\text { Listed insurers are expected to observe a Corporate Governance Code, based on } \\
\text { the "comply or explain" approach. Nonlisted companies are invited to follow the } \\
\text { recommendations of such Code. } \\
\text { BaFin does not legally require mutuals to observe the Code, but it does expect } \\
\text { them to introduce equivalent procedures. } \\
\text { Specific requirements to ensure a proper business organization including a risk } \\
\text { strategy and a risk management are applicable to all the insurers from } 2007 \text { (VAG). } \\
\text { A risk report as well as an audit report is annually submitted to the supervisor. } \\
\text { In } 2009 \text {, BaFin issued a circular on good remuneration practices based on the } \\
\text { Financial Stability Board (FSB) Principles and the recommendations of the } \\
\text { European Commission, which is applicable also to insurance holding companies } \\
\text { and insurance special purpose entities as well as at the group level or financial } \\
\text { conglomerate level. } \\
\text { In July 2010, the FSB requirements on remuneration were transposed into a } \\
\text { specific law that now requires a remuneration committee to design and further } \\
\text { develop the remuneration systems and prepare a report at least once a year } \\
\text { (remuneration report). } \\
\text { Comprehensive requirements on the position, tasks, and responsibilities of the }\end{array}$ \\
\hline
\end{tabular}




\begin{tabular}{|c|c|}
\hline & $\begin{array}{l}\text { appointed actuary are defined, which grants direct access to the management } \\
\text { board. }\end{array}$ \\
\hline Assessment & Observed. \\
\hline Comments & $\begin{array}{l}\text { BaFin has recently introduced new requirements for insurers, which strengthened } \\
\text { the robustness of its assessment of insurers' corporate governance. Those } \\
\text { measures can be seen as an anticipation of the Pillar } 2 \text { requirements, which will } \\
\text { come into force in } 2013 \text { under Solvency II. } \\
\text { It will be important to continue to check that mutuals do in fact follow procedures } \\
\text { equivalent to the corporate governance code, and adapt those procedures as } \\
\text { needed as Solvency II is introduced. }\end{array}$ \\
\hline Principle 10. & $\begin{array}{l}\text { Internal controls } \\
\text { The supervisory authority requires insurers to have in place internal controls that } \\
\text { are adequate for the nature and scale of the business. The oversight and reporting } \\
\text { systems allow the board and management to monitor and control the operations. }\end{array}$ \\
\hline Description & $\begin{array}{l}\text { The system of internal controls has been enhanced by way of issuing some } \\
\text { specific requirements (e.g., Circular } 3 / 2009 \text { on the minimum requirements for risk } \\
\text { management in insurance undertakings (MaRisk Circular)) which are aimed at } \\
\text { anticipating the future requirements under Solvency II. } \\
\text { Insurers should align their internal controls with the nature, size, risks, and } \\
\text { complexity of their activities. } \\
\text { BaFin is allowed to review all business documents and carry out on site } \\
\text { inspections and to require strengthening of internal controls where necessary. } \\
\text { Specific provisions on internal controls are further elaborated in the Ordinance on } \\
\text { the Investment of Restricted Assets. } \\
\text { Furthermore, the statutory audit report has to contain information on the } \\
\text { organization of the internal audit unit and internal control procedures implemented } \\
\text { within the insurance company in the fields of accounting and the use of derivatives. } \\
\text { The German Corporate Governance Code requires the supervisory board to set up } \\
\text { an audit committee, which, in particular, handles issues of accounting, risk } \\
\text { management and compliance, the necessary independence required of the auditor, } \\
\text { the issuing of the audit mandate to the auditor, the determination of auditing focal } \\
\text { points, and the fee agreement. The chairman of the audit committee shall have } \\
\text { specialist knowledge and experience in the application of accounting principles and } \\
\text { internal control processes. He should be independent and not be a former member } \\
\text { of the management board of the company whose appointment ended less than two } \\
\text { years ago. } \\
\text { However, all larger insurance companies are required to have an internal audit } \\
\text { function, which has to be granted direct access to the management board. } \\
\text { As part of the internal control, an independent actuarial trustee has to approve a } \\
\text { change in the premiums of life insurance contracts with effect for existing contracts } \\
\text { as well as changes to health insurance premiums, when conducted in the manner } \\
\text { of life insurance. } \\
\text { Outsourcing agreements have to form part of the risk management, and the } \\
\text { insurance undertaking is required to submit important outsourcing agreement }\end{array}$ \\
\hline
\end{tabular}




\begin{tabular}{|c|c|}
\hline & $\begin{array}{l}\text { (Funktionsausgliederungsverträge) to BaFin, which makes sure that the } \\
\text { outsourced functions remain subject to the undertaking's normal internal controls. } \\
\text { BaFin is empowered to request internal control reports which are usually examined } \\
\text { during on-site inspections. } \\
\text { A risk report and an audit report, however, are submitted to BaFin each year. The } \\
\text { report, which the management board receives from the appointed actuary in life } \\
\text { insurance, has to be forwarded to BaFin. }\end{array}$ \\
\hline Assessment & Observed. \\
\hline Comments & $\begin{array}{l}\text { BaFin has articulated clearly its supervisory expectation of insurers in } \\
\text { implementing appropriate internal controls tailored to the nature, scale and } \\
\text { complexity of their operations. As for other areas of supervision, measures were } \\
\text { introduced to enhance the insurers' internal controls systems in view of the } \\
\text { incoming implementation of Solvency II. }\end{array}$ \\
\hline \multicolumn{2}{|c|}{ Ongoing Supervision } \\
\hline Principle 11. & $\begin{array}{l}\text { Market analysis } \\
\text { Making use of all available sources, the supervisory authority monitors and } \\
\text { analyses all factors that may have an impact on insurers and insurance markets. It } \\
\text { draws the conclusions and takes action as appropriate. }\end{array}$ \\
\hline Description & $\begin{array}{l}\text { BaFin carries out regular analysis of market conditions for internal and external } \\
\text { purposes. The main results are published in the annual reports of BaFin or in its } \\
\text { monthly bulletins BaFin Journal. } \\
\text { BaFin monitors and analyzes all factors that may have an impact on insurers and } \\
\text { the insurance market. An ad hoc office in the insurance directorate has been set } \\
\text { up and provides regular reports to the executive board and staff. Those reports are } \\
\text { published internally and/or externally. } \\
\text { The market analysis aims to identify trends, so that BaFin is well prepared to take } \\
\text { action at an early stage. In addition to annual and quarterly regular reports, } \\
\text { insurance companies are required to conduct scenario analysis and report the } \\
\text { results to BaFin twice a year. } \\
\text { BaFin uses stress tests to check whether or not the insurance companies would } \\
\text { still be able-even in the absence of countermeasures-to meet their accrued } \\
\text { obligations to policyholders (e.g., to cover technical provisions and own funds } \\
\text { requirements with the appropriate assets) including in the event of an ongoing } \\
\text { crisis on the capital market. This allows BaFin to identify those companies that do } \\
\text { not have an appropriate investment policy that enables them to cover risks. The } \\
\text { main outcomes of such kinds of analyses are reported to the board of BaFin as } \\
\text { well as to the federal ministry of finance. } \\
\text { Microprudential stress tests for all German insurers are regularly carried out under } \\
\text { BaFin guidance, while from time to time the Bundesbank analyzes the sector's risk } \\
\text { from a top-down perspective. All (approximately } 600 \text { ) German insurers have been } \\
\text { running stress tests since } 2004 \text { based on guidance (particularly on the scenarios) } \\
\text { provided by BaFin. Ad hoc tests are run; recently, for example, an analysis of the } \\
\text { impact of a low interest rate scenario has been published in the } 2010 \text { Financial } \\
\text { Stability Review issued by Bundesbank. } \\
\text { The tests assess a potential reduction of the value of the assets under stress, }\end{array}$ \\
\hline
\end{tabular}




\begin{tabular}{|c|c|}
\hline & $\begin{array}{l}\text { accounting for asset price risks (for bonds, equity and property prices) and credit } \\
\text { risk (determined by external ratings) of individual companies. On the liability side, } \\
\text { the solvency requirements according to Solvency I are used as a buffer against } \\
\text { technical provisions. Estimates account for the growth of business, risk mitigations } \\
\text { (through hedging operations), hidden reserves (due to German accounting rules) } \\
\text { and specific insurer risk elements (free provisions for bonuses and rebates, } \\
\text { provision due to unit linked products, participation on valuation reserves) Recently, } \\
\text { analysis was conducted on sovereign risk exposure, low interest rates, "toxic } \\
\text { assets," and other less-standard investment vehicles (such as hedge funds, } \\
\text { private equity funds, and asset-based securities). } \\
\text { Aggregated market data is published in the annual report of BaFin, which is easily } \\
\text { available. }\end{array}$ \\
\hline Assessment & Observed. \\
\hline Comments & $\begin{array}{l}\text { BaFin performs market analysis to identify, assess, and mitigate risks to the } \\
\text { insurance sector. } \\
\text { Stress tests will need to be regularly revised and adopted to Solvency II. The tests } \\
\text { appear adequate for most risks and most (smaller) insurers, but should be } \\
\text { complemented by sophisticated tests for the larger insurers, as is envisaged by } \\
\text { European Insurance and Occupational Pensions Authority (EIOPA) according to } \\
\text { the press release of } 13 \text { January, } 2011 \text {. The authorities should consider running } \\
\text { multi-period tests on a regular basis; the insurance sector tends to be affected by } \\
\text { slower-moving trends rather than short-term shocks, and feedback through } \\
\text { profitability and retained earnings is likely to be strong. Efforts should be made to } \\
\text { improve the analysis of group-wide stability and linkages to the banking sector, } \\
\text { notably where insurance companies belong to financial conglomerates and cross- } \\
\text { sectioned associations. }\end{array}$ \\
\hline Principle 12. & $\begin{array}{l}\text { Reporting to supervisors and off-site monitoring } \\
\text { The supervisory authority receives necessary information to conduct effective off- } \\
\text { site monitoring and to evaluate the condition of each insurer as well as the } \\
\text { insurance market. }\end{array}$ \\
\hline Description & $\begin{array}{l}\text { Insurers are required to submit regular financial reports to BaFin, which include } \\
\text { financial statements; annual reports; the actuary's report; solvency notifications on } \\
\text { a solo as well as group-wide basis; auditors' reports; notifications on the } \\
\text { investment portfolio and the acquisition of specific assets; and reports on } \\
\text { intragroup transactions. Life insurers must submit an actuarial basis for premium } \\
\text { rating and technical provisions for new products introduced. } \\
\text { Circulars regulate different kinds of reporting concerning investments, including } \\
\text { structured products, derivative financial instruments, asset-backed securities, and } \\
\text { credit-linked notes. Furthermore, companies must report on the coverage of their } \\
\text { technical liabilities with eligible investments on the basis of both book and market } \\
\text { values. } \\
\text { The majority of reports are provided annually, but BaFin also receives reports on a } \\
\text { quarterly basis (investments and coverage of technical liabilities). Most of the } \\
\text { reports contain figures for the previous end of year or quarter, but forward-looking } \\
\text { pro forma reports such as stress tests and scenario reports are also required. } \\
\text { The annual accounts of all insurance undertakings must be audited by external } \\
\text { auditors, except for small insurers whose accounts are audited at least every three }\end{array}$ \\
\hline
\end{tabular}




\begin{tabular}{|c|c|}
\hline & $\begin{array}{l}\text { years. } \\
\text { As regard to valuation criteria, prudent principles are established for asset and } \\
\text { liabilities. In particular, insurers are not permitted to value assets at amounts } \\
\text { exceeding the purchase price, while they must write assets down if any loss in } \\
\text { their value is probably permanent, and they may write them down if any loss in } \\
\text { value is probably temporary. Profits may not be shown unless they have been } \\
\text { realized, whereas losses have to be shown even if they are only anticipated. The } \\
\text { concrete application of such principles is driven by specific provisions envisaged } \\
\text { by the auditors' association which contain quantitative thresholds and time-length } \\
\text { to determine when writing down an asset. The application of such provisions } \\
\text { needs to be disclosed. } \\
\text { At least on an annual basis BaFin meets the auditors' association to discuss and } \\
\text { analyze the main relevant topics for supervision. } \\
\text { BaFin requires both the book and market values to be included in the supervisory } \\
\text { reporting on assets. } \\
\text { The prudential returns also include information on off-balance sheet activities, } \\
\text { outsourced functions, and activities. Outsourcing contracts have to be submitted to } \\
\text { BaFin to become valid. BaFin has the right to review these contracts at any time. } \\
\text { In cases of irregularities, BaFin may dismiss a contract or require changes to a } \\
\text { contract. } \\
\text { Reporting requirements do not distinguish between legal form and jurisdiction of } \\
\text { origin of an insurer, but are driven only by prudential considerations. } \\
\text { BaFin can enforce the submission of reports and specific sanctions/fines for } \\
\text { breaches of obligations are foreseen even though hardly used. } \\
\text { In } 2002 \text {, BaFin introduced forward-looking reports such as stress tests and } \\
\text { scenario calculations. } \\
\text { There is no direct obligation for the supervised entity to promptly communicate to } \\
\text { the supervisor material changes that affect its condition unless it is already } \\
\text { insolvent. }\end{array}$ \\
\hline Assessment & Observed. \\
\hline Comments & $\begin{array}{l}\text { BaFin has a systematic process to review regulatory returns and information } \\
\text { provided by insurers as part of its offsite surveillance. The supervisory returns take } \\
\text { advantage of the auditor assessment performed on the financial statement. } \\
\text { It is advisable to introduce an explicit obligation for the prompt notification of } \\
\text { supervisors by insurers and auditors of any material changes which affect the } \\
\text { current or foreseeable financial condition of an institution. } \\
\text { The authorities will have to remain vigilant that reporting requirements stay up to } \\
\text { date: some variables may gain in importance, for example, under Solvency II, } \\
\text { while other data on variables may cease to be worth collecting. Care should } \\
\text { continue to be taken to contain the regulatory burden, for example, by harmonizing } \\
\text { and centralizing to the extent possible reporting requirements imposed by } \\
\text { authorities in different jurisdictions or for different purposes. }\end{array}$ \\
\hline
\end{tabular}




\begin{tabular}{|c|c|}
\hline Principle 13. & $\begin{array}{l}\text { On-site inspection } \\
\text { The supervisory authority carries out on-site inspections to examine the business } \\
\text { of an insurer and its compliance with legislation and supervisory requirements. }\end{array}$ \\
\hline Description & 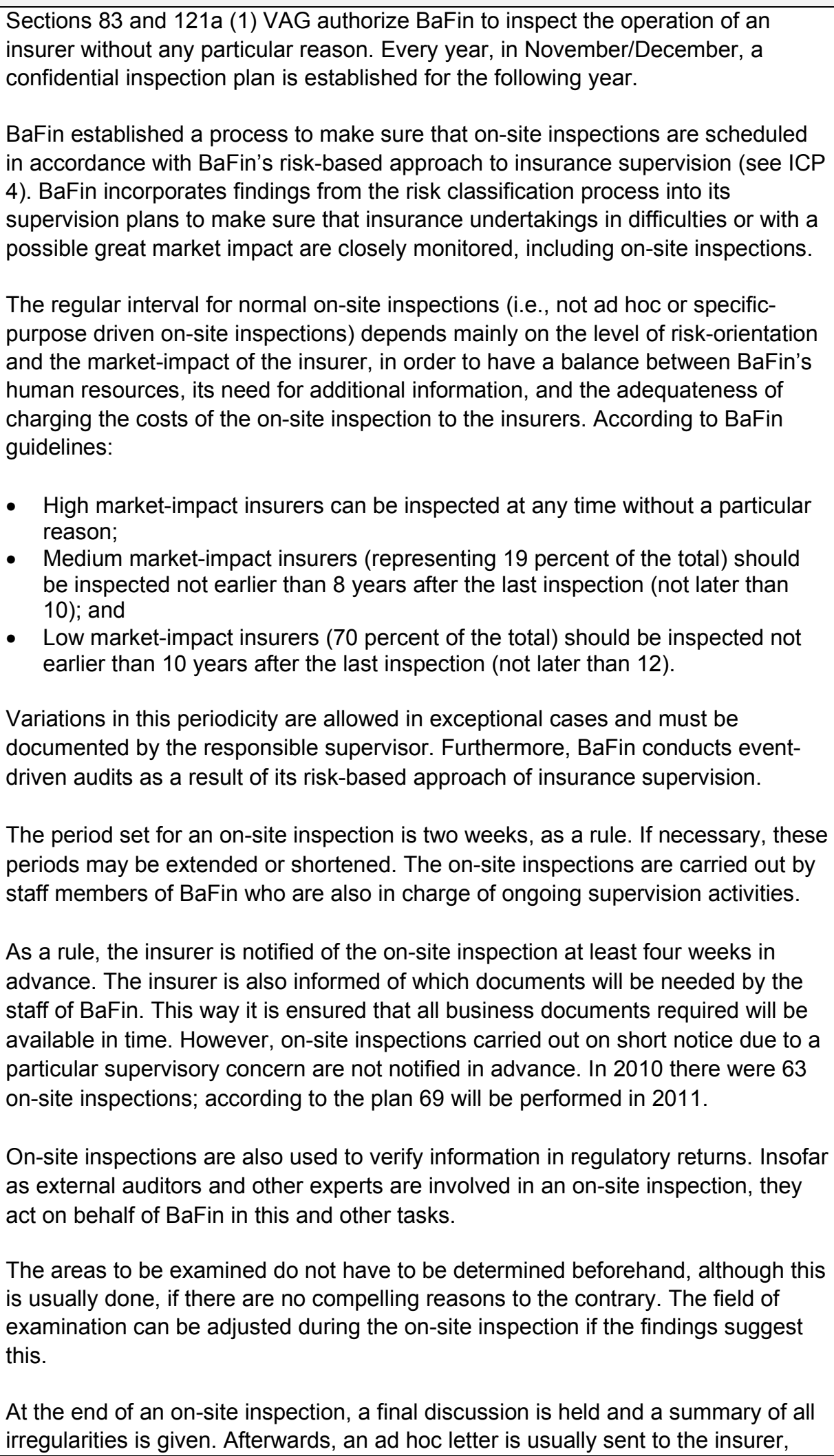 \\
\hline
\end{tabular}




\begin{tabular}{|c|c|}
\hline & $\begin{array}{l}\text { which is obliged to remedy the irregularities listed immediately. If the insurer does } \\
\text { not or not fully meet this obligation within a fixed period of time, BaFin may take } \\
\text { suitable actions to enforce it. } \\
\text { The power to carry out on-site inspections extends to other persons or companies } \\
\text { if they render services to the insurer such as insurance intermediaries, outsourced } \\
\text { companies or persons. }\end{array}$ \\
\hline Assessment & Observed. \\
\hline Comments & $\begin{array}{l}\text { BaFin conducts on-site inspections, which are prioritized based on an analysis of } \\
\text { insurers' risk profiles and its market impact. It also has recently conducted joint on- } \\
\text { site inspections with other supervisors to address specific issues. } \\
\text { However, the frequency of regular on-site inspection for the medium- and low- } \\
\text { impact insurers is low, and should be increased. While resources allocation } \\
\text { should indeed be prioritized according to assessed risks, the chance of detecting } \\
\text { emerging difficulties would be importantly increased if at least brief inspection } \\
\text { visits were conducted every three or four years for medium-sized insurers. }\end{array}$ \\
\hline Principle 14. & $\begin{array}{l}\text { Preventive and Corrective Measures } \\
\text { The supervisory authority takes preventive and corrective measures that are } \\
\text { timely, suitable and necessary to achieve the objectives of insurance supervision. }\end{array}$ \\
\hline Description & $\begin{array}{l}\text { As a first step for achieving complaint behavior, BaFin uses informal measures } \\
\text { such as guidance notes in circulars, informal requests stemming from on-site } \\
\text { inspections or regular report analysis, and meetings and communications with } \\
\text { insurers as well as with the associations. } \\
\text { Pursuant to the general provisions of sections } 81 \text { (2) and } 81 \text { b VAG in conjunction } \\
\text { with section 121a VAG for reinsurance undertakings, in conjunction with section } \\
104 \mathrm{~h} \text { VAG for insurance groups and in conjunction with section 104t VAG for } \\
\text { conglomerates, BaFin is entitled to take any measures (including measures of } \\
\text { progressive escalation), which are appropriate and necessary to prevent or } \\
\text { remedy irregularities. Any conduct of an insurance undertaking, which conflicts } \\
\text { with the supervisory objectives pursuant to section } 81 \text { (1) VAG, is considered an } \\
\text { irregularity. } \\
\text { For preventing and correcting irregularities, BaFin is entitled to intervene, for } \\
\text { example, by: } \\
\text { requiring the dismissal of members of the management board (section } 87 \text { (6) } \\
\text { VAG), appointing a special representative (section } 83 \text { a VAG), or, as a last } \\
\text { resort, revoking the license; or } \\
\text { requiring an insurer to propose a restructuring scheme if it fails to meet the } \\
\text { minimum solvency margin. If the insurer's solvency falls below the required } \\
\text { guarantee, it has to submit a financing scheme. }\end{array}$ \\
\hline Assessment & Observed. \\
\hline Comments & $\begin{array}{l}\text { In line with the EU directives, BaFin is empowered to take a range of preventative } \\
\text { measures, which allows a progressive escalation of supervisory actions to respond } \\
\text { to emerging concerns. The implementation of Solvency II will imply further } \\
\text { increase of flexibility in the possible supervisory actions by introducing a more } \\
\text { specific intervention ladder based on the solvency ratios. } \\
\text { The level of sanctions will need to be kept under review to ensure that they remain } \\
\text { effective as deterrents. }\end{array}$ \\
\hline
\end{tabular}




\begin{tabular}{|c|c|}
\hline Principle 15. & $\begin{array}{l}\text { Enforcement or sanctions } \\
\text { The supervisory authority enforces corrective action and, where needed, imposes } \\
\text { sanctions based on clear and objective criteria that are publicly disclosed. }\end{array}$ \\
\hline Description & $\begin{array}{l}\text { In deciding whether to take enforcement action, going beyond preventive and } \\
\text { corrective measures, BaFin takes into account the seriousness of breaches of } \\
\text { rules and regulations, guided by its supervisory judgment. } \\
\text { BaFin may take the following enforcement measures in respect of insurers who fail } \\
\text { to comply with the VAG: } \\
\text { - Prohibit payments to shareholders, policyholders and other persons if there is } \\
\text { a risk of the insurance undertaking becoming insolvent. } \\
\text { - Prohibit the transfer of assets and the buyback of the undertaking's own } \\
\text { shares. } \\
\text { - Impose restrictions on the free disposal of assets in connection with a } \\
\text { restructuring or financing scheme. } \\
\text { - Require the supervisory board to dismiss management board members who } \\
\text { have been found technically unqualified or unreliable. Before such a measure } \\
\text { is taken, BaFin can advise the insurer both informally (first step) and more } \\
\text { formally (second step) by issuing a caution "yellow card." } \\
\text { - Appoint a special commissioner to whom may be transferred the powers of } \\
\text { the management board. } \\
\text { - Withdraw the license for failure to meet licensing requirements. } \\
\text { - Report criminal offences to the Public Prosecutor's Office } \\
\text { Apply to the court for the opening of an insolvency proceeding (refer ICP 16). } \\
\text { Instructions issued by BaFin are immediately enforceable or may be declared so } \\
\text { by BaFin. In such cases, instructions can be compulsorily enforced even if they } \\
\text { have been contested or a case has been brought before the administrative court. } \\
\text { A special representative can also be engaged to implement action needed. } \\
\text { BaFin may impose administrative fines, which power, however, is rarely concretely } \\
\text { used. }\end{array}$ \\
\hline Assessment & Observed. \\
\hline Comments & $\begin{array}{l}\text { BaFin takes a proportionate approach in exercising its enforcement powers under } \\
\text { the VAG. The use of administrative fines is considered to be rarely necessary due } \\
\text { to the fact that insurers in general comply even with initial informal requests from } \\
\text { the authorities. }\end{array}$ \\
\hline Principle 16. & $\begin{array}{l}\text { Winding-up and exit from the market } \\
\text { The legal and regulatory framework defines a range of options for the orderly exit } \\
\text { of insurers from the marketplace. It defines insolvency and establishes the criteria } \\
\text { and procedure for dealing with insolvency. In the event of winding-up proceedings, } \\
\text { the legal framework gives priority to the protection of policyholders. }\end{array}$ \\
\hline Description & $\begin{array}{l}\text { The event triggering action by BaFin is the insurer's insolvency or imminent } \\
\text { illiquidity. From the time this occurs, BaFin may apply to the competent court for } \\
\text { the opening of an insolvency proceeding. } \\
\text { The criteria and procedures for dealing with insolvency are established by VAG } \\
\text { (including cooperation with other European insurance supervisors), while } \\
\text { Insurance Contract Act (VVG) contains provisions on the treatment of insurance } \\
\text { contracts. All other matters are governed by the general German Insolvency } \\
\text { Statute (Insolvenzordnung (InsO)). }\end{array}$ \\
\hline
\end{tabular}




\begin{tabular}{|c|c|}
\hline & $\begin{array}{l}\text { BaFin also supervises the voluntary liquidation and run off in case of revoke of the } \\
\text { license or prohibition to underwrite new business. } \\
\text { In the event of winding up proceedings, insurance related claims are protected by } \\
\text { the guarantee assets and rank prior to the claims of the remaining insolvency } \\
\text { creditors in the amount of the share of guarantee assets. The priority of insurance } \\
\text { related claims does not apply to reinsurers. } \\
\text { Statutory insolvency protection schemes are in place (protektor, medicator) for life } \\
\text { and substitutive health insurance. BaFin is empowered to transfer a life or health } \\
\text { portfolio of the insolvent primary insurer to one of these schemes. } \\
\text { A default fund for the motor vehicle third-party liability insurance sector has been in } \\
\text { existence for decades in conformance with the relevant EU Directives. }\end{array}$ \\
\hline Assessment & Observed. \\
\hline Comments & $\begin{array}{l}\text { Legislation provides for orderly exits of insurers and a high degree of protection for } \\
\text { policyholders in the event of insolvency. }\end{array}$ \\
\hline Principle 17. & $\begin{array}{l}\text { Group-wide supervision } \\
\text { The supervisory authority supervises its insurers on a solo and a group-wide basis. }\end{array}$ \\
\hline Description & $\begin{array}{l}\text { The legislation, largely based on the EU directives, clearly defines the } \\
\text { undertakings, which are subject to group-wide supervision both within the } \\
\text { insurance sector (insurance groups) and cross-sector (financial conglomerates). } \\
\text { BaFin holds the list of such groups. It has to be noted that the top } 5 \text { insurance } \\
\text { groups hold } 49 \text { percent of the market share as at end-2009. } \\
\text { The collaboration of the insurance supervisors within the EU is regulated in a } \\
\text { protocol, which was adopted on May } 11,2000 \text {. Under this protocol, specific } \\
\text { provisions are fixed to initiate, encourage, and facilitate the practical cooperation } \\
\text { between the relevant supervisors of a cross-border group. BaFin also has signed } \\
\text { additional MoUs (see ICP 5). In recent years, the use of supervisory colleges has } \\
\text { increased quite a lot also in view of the forthcoming additional requirements that } \\
\text { will be set under Solvency II. } \\
\text { BaFin has an internal guideline for group-wide supervision, which includes } \\
\text { supervisory tools, risk indicators and their role as warning signals, explanations on } \\
\text { how to perform the coordination with other relevant supervisors both when leading } \\
\text { the process and when BaFin is a host supervisor. } \\
\text { BaFin has internally assigned a center of expertise for group-wide supervision, and } \\
\text { there is also an internal list over the group-wide supervisors of particular groups } \\
\text { that links the groups and their solo entities together as the companies are not } \\
\text { necessarily supervised by the same department. Furthermore, lead supervisors } \\
\text { compile group risk profiles regularly. } \\
\text { The legislation provides for the reporting of information to the supervisor } \\
\text { mentioning intragroup transactions, adjusted solvency requirements to avoid } \\
\text { multiple gearing of capital, internal control mechanisms, and risk management } \\
\text { processes. }\end{array}$ \\
\hline
\end{tabular}




\begin{tabular}{|c|c|}
\hline & $\begin{array}{l}\text { BaFin may take enforcement action against regulated entities that are part of a } \\
\text { financial conglomerate if there are risks that their solvency might be jeopardized or } \\
\text { the intragroup contracts and positions or the risk concentrations threaten the } \\
\text { financial position of that regulated entity. }\end{array}$ \\
\hline Assessment & Observed. \\
\hline Comments & $\begin{array}{l}\text { The German regulatory frameworks for insurance groups and conglomerates are } \\
\text { broadly in line with EU directives. The impending implementation of Solvency II will } \\
\text { strengthen BaFin's supervision of insurance groups, subject to the adequacy of } \\
\text { regulatory resources. } \\
\text { In this regard it is advisable to consider: } \\
\text { - Increasing the adequacy of resources, particularly for the effective supervision } \\
\text { of international active groups/conglomerates. } \\
\text { - Developing the risk classification tool (see ICP 4) to include the group-wide } \\
\text { supervision. } \\
\text { Harmonizing the supervisory approach in the area of group capital adequacy } \\
\text { calculation by issuing more detailed rules on, inter alia, the treatment of } \\
\text { participation in credit institutions, the valuation criteria to be used. } \\
\text { Group-wide stress tests, taking into account if need be linkages to other financial } \\
\text { institutions, should be performed more regularly. }\end{array}$ \\
\hline \multicolumn{2}{|c|}{ Prudential Requirements } \\
\hline & $\begin{array}{l}\text { Risk assessment and management } \\
\text { The supervisory authority requires insurers to recognize the range of risks that } \\
\text { they face and to assess and manage them effectively. }\end{array}$ \\
\hline Description & $\begin{array}{l}\text { Insurers are required to possess a proper business organization including a risk } \\
\text { strategy and risk management system and to submit risk and audit reports to } \\
\text { BaFin each year (sections 55c and 64a VAG). } \\
\text { BaFin has supplemented these provisions requiring insurers to have their systems } \\
\text { capable of promptly identifying, measuring, assessing, reporting, and controlling } \\
\text { their risks. Tolerance levels have to be established. The risk management system } \\
\text { has to be appropriate to the size, nature, and complexity of the business. BaFin } \\
\text { requires insurers to manage all material risks, which should include at least an } \\
\text { examination of the underwriting, market, and credit risks, including country, } \\
\text { concentration, liquidity, operational, strategic as well as reputational risks. } \\
\text { Particularly for investment risk, insurers are required to ensure that investment } \\
\text { principles laid down in VAG are observed by qualified investment managers, and } \\
\text { that suitable internal investment principles and control procedures, a forward- } \\
\text { looking investment policy, and other organizational measures are in place. The } \\
\text { detailed rules relating to these provisions are contained in specific circular } 15 / 2005 \\
\text { (VA). } \\
\text { According to this circular, insurers must be able to identify, assess, control, and } \\
\text { report on the risks associated with their investment activities. } \\
\text { The task of risk management must be carried out by a unit of the undertaking that } \\
\text { is responsible for: } \\
\text { - Monitoring compliance with the investment policy that has been laid down. } \\
\text { Formally identifying contraventions and reporting them immediately to the } \\
\text { management board. }\end{array}$ \\
\hline
\end{tabular}




\begin{tabular}{|c|c|}
\hline & $\begin{array}{l}\text { Examining the asset/liability situation and the liquidity position. } \\
\text { Risk management must also assess whether the internal investment limits are } \\
\text { appropriate and whether the undertaking is in a position at all times to fulfill its } \\
\text { insurance obligations in light of its available risk-bearing capacity and the risk } \\
\text { guidelines (e.g., maximum total write-offs). For this purpose stress tests need to be } \\
\text { conducted at least every quarter. } \\
\text { Specific rules address the risk management in the case of direct and indirect } \\
\text { investments in hedge funds. } \\
\text { The German Corporate Governance Code has strengthened the supervisory } \\
\text { board's control function, requiring this board to set up an audit committee, which, } \\
\text { in particular, handles accounting and risk management issues. } \\
\text { The BaFin circular also obliges insurers to have a risk management function } \\
\text { according to the size, nature, and complexity of the business. Risk management } \\
\text { committees are established in several German insurers even though this is not } \\
\text { required by German law. Specific reporting requirements to BaFin are foreseen on } \\
\text { an annual basis. }\end{array}$ \\
\hline Assessment & Observed. \\
\hline Comments & $\begin{array}{l}\text { The VAG has established high-level requirements relating to insurers' risk } \\
\text { management, supplemented by BaFin circular and supervisory expectation. The } \\
\text { effectiveness of insurers' risk management system is assessed by BaFin under its } \\
\text { supervisory review process. The risk management requirements can be seen as } \\
\text { an anticipation of Solvency II which will come into force in } 2013 \text {. }\end{array}$ \\
\hline & $\begin{array}{l}\text { Insurance activity } \\
\text { Since insurance is a risk taking activity, the supervisory authority requires insurers } \\
\text { to evaluate and manage the risks that they underwrite, in particular through } \\
\text { reinsurance, and to have the tools to establish an adequate level of premiums. }\end{array}$ \\
\hline Description & $\begin{array}{l}\text { BaFin's supervisory expectations include strategic underwriting and pricing } \\
\text { policies, the evaluation and diversification of risks, the maintenance of an } \\
\text { adequate level of premiums, and an appropriate reinsurance cover as part of an } \\
\text { appropriate insurance business. } \\
\text { BaFin's monitoring is carried out on the basis of very detailed internal reporting } \\
\text { and notification requirements, ad hoc information requests and on-site inspections, } \\
\text { that generally include the review of risk management, general insurance policy } \\
\text { rates, technical reserves, minutes of the management board and supervisory } \\
\text { board meetings, claims handling, provisions and investments. } \\
\text { A specific legal base for the review of premiums exists only for primary life } \\
\text { insurance and accident insurance with a return of premium. The monitoring is } \\
\text { carried out by means of extensive notification requirements for life insurance, } \\
\text { which do comprise any amendments of the principles of calculation of the } \\
\text { premiums and mathematical provisions including the calculation bases, } \\
\text { mathematical formulas, imputed derivations, and statistical evidence used. } \\
\text { For all other primary insurance classes, premiums are reviewed by BaFin indirectly } \\
\text { by the assessment whether an insurance undertaking provides adequate } \\
\text { provisions in order to meet its liabilities at all times. } \\
\text { For required health insurance, the method of reassessing premiums periodically is }\end{array}$ \\
\hline
\end{tabular}




\begin{tabular}{|c|c|}
\hline & $\begin{array}{l}\text { specified in detail by law. Any change of premiums needs prior approval by an } \\
\text { independent trustee. } \\
\text { Reinsurance undertakings are subject to an equivalent supervision with regard to } \\
\text { retrocession and an adequate level of premiums. BaFin may, with respect to the } \\
\text { undertakings, the members of their management board and other managers or } \\
\text { individuals controlling the undertaking, take any orders, which are appropriate and } \\
\text { necessary to ensure that reinsurance undertakings are able at all times to meet } \\
\text { their obligations arising from the reinsurance relationships. This includes a } \\
\text { sufficient protection by means of retrocession as well as a sound premium level. } \\
\text { BaFin is empowered to adjust the value of an insurer's reinsurance recoverable to } \\
\text { a lower value than shown in its accounts or to disqualify certain assets covering } \\
\text { technical provision, if deemed appropriate. } \\
\text { Accounting requirements do not allow for recognition of risk mitigation instruments } \\
\text { where such instruments do not constitute effective risk transfer. }\end{array}$ \\
\hline Assessment & Observed. \\
\hline Comments & $\begin{array}{l}\text { BaFin directly reviews premium pricing for some classes of business and monitors } \\
\text { insurance risks through its assessment of insurers' risk management system and } \\
\text { technical provisions. }\end{array}$ \\
\hline Principle 20. & $\begin{array}{l}\text { Liabilities } \\
\text { The supervisory authority requires insurers to comply with standards for } \\
\text { establishing adequate technical provisions and other liabilities, and making } \\
\text { allowance for reinsurance recoverables. The supervisory authority has both the } \\
\text { authority and the ability to assess the adequacy of the technical provisions and to } \\
\text { require that these provisions be increased, if necessary. }\end{array}$ \\
\hline Description & $\begin{array}{l}\text { The law requires an insurer to establish adequate technical provisions. The } \\
\text { relevant provisions are included in the insurance accounting rules as well as in the } \\
\text { ordinances on mathematical provisions that lay within the responsibility of the } \\
\text { federal ministry of justice and the federal ministry of finance. BaFin is consulted } \\
\text { during the legislative process. } \\
\text { BaFin is empowered to assess the adequacy of the technical provisions and to } \\
\text { require that these provisions be increased, if necessary. } \\
\text { The mathematical provision is to be calculated for each contract and (if possible) } \\
\text { prospectively. The federal ministry of finance issues provisions for the purpose of } \\
\text { calculating the mathematical provision and fixes: } \\
\text { - The maximum technical interest rate. } \\
\text { - The maximum rate of zillmerization. } \\
\text { Biometric calculation bases are not prescribed, although BaFin recommends the } \\
\text { tables be published by the actuarial association. However, an insurance } \\
\text { undertaking may also develop and use its own biometric tables as long as they are } \\
\text { appropriate and adequate for the undertaking's specific insurance portfolio. } \\
\text { Nonlife insurers shall maintain technical provisions that are adequate to cover } \\
\text { unearned premiums, outstanding claims, and incurred but not reported claims. } \\
\text { Discounting of nonlife technical provision is not allowed. Rules on the calculation } \\
\text { of the equalization provision are defined. }\end{array}$ \\
\hline
\end{tabular}




\begin{tabular}{|c|c|}
\hline & $\begin{array}{l}\text { BaFin reviews the sufficiency of technical provisions in particular during on-site } \\
\text { inspections. Moreover, insurance companies are required to submit annual and } \\
\text { auditors' report to enable BaFin to recognize negative developments. } \\
\text { In addition, the responsible appointed actuary of a primary insurance company } \\
\text { certifies that the bases for the calculation of the mathematical provision are } \\
\text { adequate. If this is not the case, BaFin may require provisions to be increased to } \\
\text { ensure that the contractual liabilities can be fulfilled at all times. } \\
\text { Even individual nonlife insurance undertakings may be asked to increase their } \\
\text { provisions if they are too low and thus inadequate for safeguarding the interests of } \\
\text { the insured. }\end{array}$ \\
\hline Assessment & Observed. \\
\hline Comments & $\begin{array}{l}\text { There are clear, legal principles and regulatory guidelines for insurers to estimate } \\
\text { their insurance liabilities. In addition, the audit reports of external auditors as well } \\
\text { as appointed actuaries for certain line of businesses can also be used. BaFin } \\
\text { monitors insurers' technical provisions by off-site examinations as well as on on- } \\
\text { site inspections and has the power to require insurers to remedy any shortfall. It is } \\
\text { recommended that, in view of the increasing complexity of the valuation criteria to } \\
\text { be used under Solvency II as well as their differences with the current ones, BaFin } \\
\text { should increase the number of its staff equipped with actuarial expertise and } \\
\text { related quantitative skills. Its current advisory function in this field could be } \\
\text { enhanced. } \\
\text { Stress tests for liability-side risks should be refined and conducted more } \\
\text { frequently. While actuarial assumptions are reportedly conservative, supervisors } \\
\text { need to assess the sensitivity of results to variations in these assumptions, and } \\
\text { other liability-side factors (such as discount rates). }\end{array}$ \\
\hline Principle 21. & $\begin{array}{l}\text { Investments } \\
\text { The supervisory authority requires insurers to comply with standards on } \\
\text { investment activities. These standards include requirements on investment policy, } \\
\text { asset mix, valuation, diversification, asset-liability matching, and risk management. }\end{array}$ \\
\hline Description & $\begin{array}{l}\text { Insurers are expected to have strategic investment and investment risk } \\
\text { management policies that are proportionate to the nature, scale, risk, profile, and } \\
\text { complexity of their operations. } \\
\text { Moreover, insurers should have an effective asset-liability management to ensure } \\
\text { that the nature of assets that are intended to cover their technical provisions are } \\
\text { appropriate for their liability profiles. } \\
\text { The investments of the guarantee assets and the other restricted assets of } \\
\text { undertaking primary insurer shall be invested in a way which ensures maximum } \\
\text { security and profitability, while maintaining the insurer's liquidity at all times, } \\
\text { through adequate mix and spread. } \\
\text { Under the law, a list of admissible assets are defined together with detailed } \\
\text { quantitative thresholds to limit the exposure toward single counterparts as well as } \\
\text { toward various investment risks (e.g., equity, sovereign, property, and currency } \\
\text { risks) to (a) guarantee the liquidity of the investment portfolio; and (b) ensure an } \\
\text { adequate level of spreading and diversification of the risks. Specific limits are also } \\
\text { fixed regarding investments that are used to transfer credit risk (such as ABS) or } \\
\text { investments in hedge funds and high-yield bonds. }\end{array}$ \\
\hline
\end{tabular}


Investments in other assets may be done (a) if it is permitted by BaFin upon request; (b) in exceptional situations; (c) for a limited period of time; and (d) if the interests of the insured are thereby not impaired.

The trustee of the guarantee assets supervises these assets for life and health insurance. The trustee must be a person who:

- Is independent of the undertaking.

- Has joint responsibility with the life or health insurer for looking after the guarantee assets and must be notified of any changes that concern the items making up the guarantee assets.

- Must resist any removal of items that would result in the technical provisions no longer being fully covered by guarantee assets.

- Must resist the addition of any items that do not meet the statutory quality criteria.

- Is required to confirm, below the balance sheet, that the pro rata unearned premium reserve created has been invested and safeguarded in accordance with the statutory and supervisory requirements.

The primary insurer may appoint a trustee only after his/her nomination has been submitted to BaFin and the latter confirms that it has no objections to the appointment (Section 71 (2) VAG). BaFin normally receives the nomination at least four weeks before the appointment is scheduled to take effect. The nomination must include, e.g., the candidate's curriculum vitae, which should provide information about the candidate's expertise, independence, other significant responsibilities and place of residence. The appointment of a reliable, qualified, and independent trustee is a requirement to conduct business.

Regarding the evaluation criteria, the basic principle is the lower-of-cost-or-market value. As an exception to this principle, insurers may treat their investments as fixed assets if and to the extent they serve business operations on a permanent basis. Consequently, insurers are required to write down values only in the event of lasting depreciations. More detailed rules governing this exception are contained in an auditors' standard agreed with BaFin. Furthermore, BaFin requests insurers to report book and current values of investments quarterly to evaluate the financial stability of the insurers and its risk bearing ability on the basis of current/market values of its investments (see ICP 12).

BaFin checks if these provisions are complied with in the course of both on-site inspections and off-site monitoring.

The investment policy must comply with the supervisory law and guidance of BaFin. In this context, the internal investment guidelines have to take into account the following elements:

- The risk profile of the insurer.

- The determination of the strategic asset allocation.

- Restrictions for the holding of some types of assets and the establishment of limits for the allocation of assets.

- Restrictions of some types of assets.

- The conditions for pledging or lending of assets.

- Overall policy on the use of financial derivatives or structured products.

- Clear accountability for all asset transactions and associated risks. 


\begin{tabular}{|c|c|}
\hline & $\begin{array}{l}\text { Suitable methods must be used for evaluating, managing, and monitoring the } \\
\text { investment risks inherent in the respective types of investments. } \\
\text { The investment policy needs to be implemented by an investment management } \\
\text { team operating with staff and material resources that are adequate for handling the } \\
\text { risks inherent in the individual investments. } \\
\text { Procedures also need to be in place for identifying and monitoring the degree to } \\
\text { which the team's efficacy may depend on and be vulnerable to certain key } \\
\text { members of staff and systems. Guidelines on staff remuneration must not provide } \\
\text { any incentive for unauthorized risk taking. } \\
\text { An insurance undertaking's internal auditing must cover all investment activities. } \\
\text { Any concerns about the investment activity must be reported to the head of } \\
\text { investment management and to the management board. } \\
\text { The risk management system has to control the asset/liability position and the } \\
\text { liquidity status. The risk management system must also evaluate whether the } \\
\text { internal investment limits are appropriate and whether fulfillment of the insurance } \\
\text { contracts is assured at all times in the light of the undertaking's risk-bearing } \\
\text { capacity and its risk guidelines (e.g., maximum amount of depreciation). For this } \\
\text { purpose, stress tests need to be carried out at least every quarter. In addition, } \\
\text { insurance undertakings must apply a model developed by BaFin and notify the } \\
\text { latter of the results. } \\
\text { As regard to the reinsurance undertakings, the investment regulations are based } \\
\text { on the so-called "prudent person principle" in order to allow professional reinsurers } \\
\text { a maximum flexibility for their investment decisions. The qualitative rules regarding } \\
\text { investment risk management and control procedures are applied. }\end{array}$ \\
\hline Assessment & Observed. \\
\hline Comr & $\begin{array}{l}\text { Regulatory requirements are in place for insurers to manage their investment risks } \\
\text { in a manner proportionate to the nature, size, complexity, and risk profile of their } \\
\text { operations. In addition, a number of specific quantitative limits are foreseen on the } \\
\text { investment activity of the primary insurance in order to guarantee an adequate } \\
\text { spread of the risks. For the reinsurance activity, the regulation follows the "prudent } \\
\text { person principle." In view of the increasing complexity of the valuation criteria to be } \\
\text { used under Solvency II, it is advisable to keep the supervisory reporting } \\
\text { requirements under review and to continue developing BaFin's internal } \\
\text { assessment and monitoring. }\end{array}$ \\
\hline Principle 22. & $\begin{array}{l}\text { The supervisory authority requires insurers to comply with standards on the use of } \\
\text { derivatives and similar commitments. These standards address restrictions in their } \\
\text { use and disclosure requirements, as well as internal controls and monitoring of the } \\
\text { related positions. }\end{array}$ \\
\hline Description & $\begin{array}{l}\text { Under the EU directives, derivatives are permitted if they are used to limit the } \\
\text { investment risk or to enable an efficient portfolio management. In Germany, } \\
\text { specific provisions are defined only for the primary insurers. } \\
\text { The use of derivatives is permitted only if their purpose is to hedge foreign } \\
\text { exchange or interest rate risks for existing assets, or to prepare the later purchase } \\
\text { of securities, or to enhance the yields from existing securities, without restricted } \\
\text { assets being inadequately covered when delivery commitments are being met. }\end{array}$ \\
\hline
\end{tabular}




\begin{tabular}{|c|c|}
\hline & $\begin{array}{l}\text { This means that neither are operations involving derivative financial instruments } \\
\text { that are permitted and whose objective is merely to build trading positions } \\
\text { (arbitrage operations), nor operations where a securities portfolio does not exist or, } \\
\text { in the case of acquisition-preparation operations, is not intended to be built (bear } \\
\text { sales). } \\
\text { Quarterly reports to BaFin are established, while disclosure requirements are fixed } \\
\text { under the relevant accounting rules. } \\
\text { The staff entrusted with the use of the new financial instruments must be } \\
\text { adequately qualified. } \\
\text { The management board of the insurer has to be informed about the scale and the } \\
\text { economic results of the use of financial instruments on a regular basis. The } \\
\text { prerequisite for this is that the management board has sufficient expertise to } \\
\text { understand these instruments. } \\
\text { The insurer's management board is requested to fix adequate internal principles } \\
\text { and procedures to ensure that they are observed and examined regularly. } \\
\text { BaFin has to be informed without delay about any amendments to the internal } \\
\text { principles, which should be checked and examined at least once a year by the } \\
\text { board. } \\
\text { Insurers are required to have in place internal controls, risk management, and } \\
\text { internal auditing functions. } \\
\text { The auditors must be able to judge the adequacy of the internal control procedures } \\
\text { by examining whether the use of financial derivatives in the areas concerned was } \\
\text { admissible. If deficiencies are detected in the control system, the management } \\
\text { board has to be notified immediately. } \\
\text { The auditing function is carried out both internally by the internal auditing and } \\
\text { externally by the auditors of the insurer. } \\
\text { products, which are a combination of investments and derivative financial } \\
\text { instruments. } \\
\text { As regards the reinsurers, the use of derivatives is permitted as long as they } \\
\text { reduce investment risks or facilitate portfolio management. }\end{array}$ \\
\hline Assessment & Largely Observed. \\
\hline Comments & $\begin{array}{l}\text { The regulatory policy and requirements for the use of derivatives by primary } \\
\text { insurers are aligned with international best practice. Quarterly reporting is also } \\
\text { defined. } \\
\text { The provisions for reinsurance activity are more general and the reporting } \\
\text { requirements less stringent. The practice of supervision helps limit concerns that } \\
\text { could arise from this looser regime. It is recommended that the prudent person } \\
\text { principle approach, which forms the basis for the supervision of reinsurers' } \\
\text { investment activity and use of derivatives, be complemented by reinforced off-site } \\
\text { and on-site monitoring of such activities. For example, thematic inspection might }\end{array}$ \\
\hline
\end{tabular}




\begin{tabular}{|c|c|}
\hline & $\begin{array}{l}\text { be under taken of the integration of an insurance group's risk management for } \\
\text { derivatives and other business. }\end{array}$ \\
\hline \multirow[t]{2}{*}{ Principle 23.} & Capital adequacy and solvency \\
\hline & $\begin{array}{l}\text { The supervisory authority requires insurers to comply with the prescribed solvency } \\
\text { regime. This regime includes capital adequacy requirements and requires suitable } \\
\text { forms of capital that enable the insurer to absorb significant unforeseen losses. }\end{array}$ \\
\hline Description & 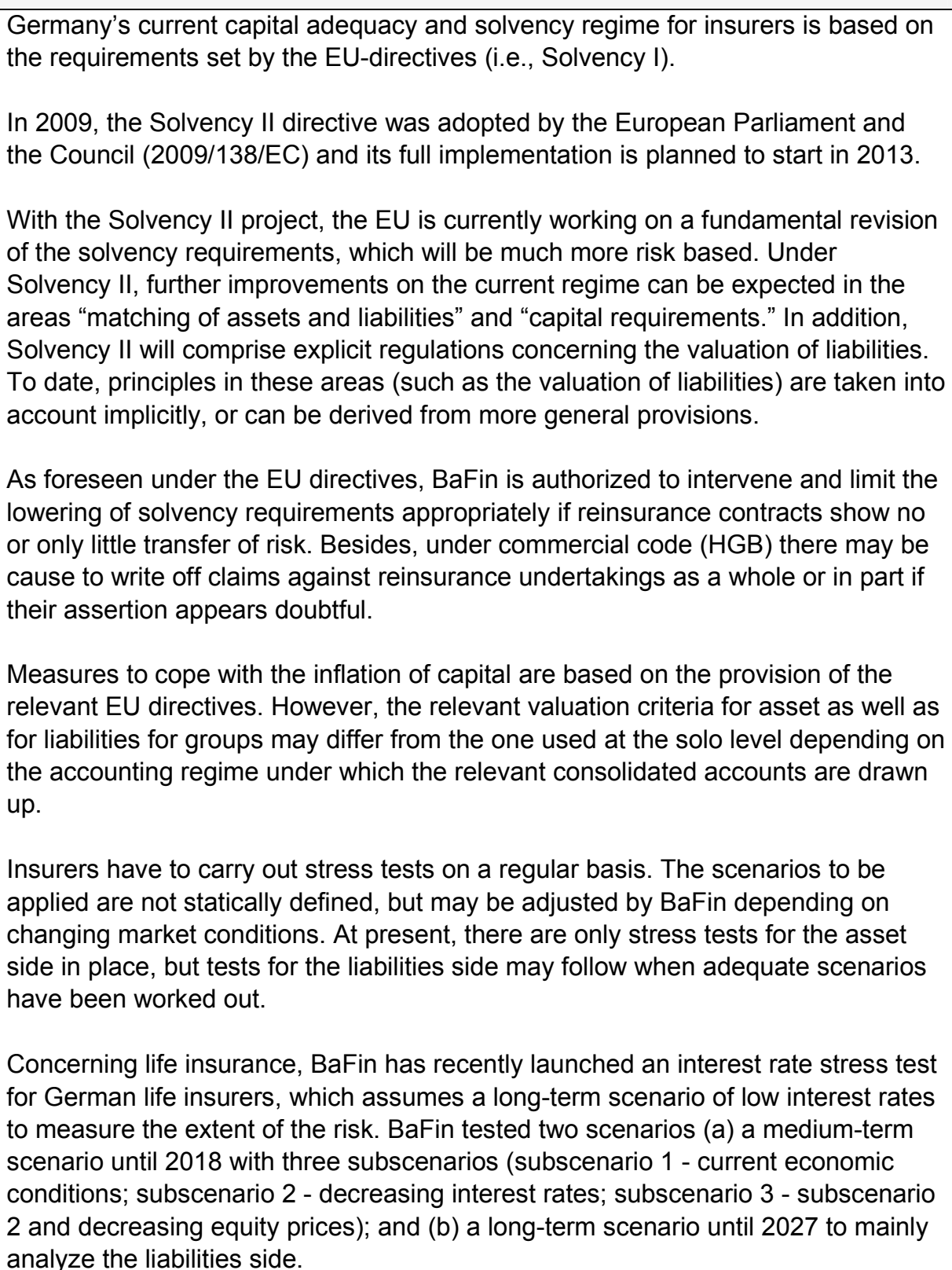 \\
\hline Assessment & Observed. \\
\hline Comments & $\begin{array}{l}\text { The capital adequacy regime is based on the EU Directives (Solvency I). The } \\
\text { implementation of Solvency II with effect from January } 2013 \text { will result in a more } \\
\text { risk-sensitive solvency regime that will enhance risk-based supervision. }\end{array}$ \\
\hline
\end{tabular}




\begin{tabular}{|c|c|}
\hline \multicolumn{2}{|c|}{ Markets and consumers } \\
\hline Principle 24. & Intermediaries \\
\hline & $\begin{array}{l}\text { The supervisory authority sets requirements, directly or through the supervision } \\
\text { of insurers, for the conduct of intermediaries. }\end{array}$ \\
\hline Description & $\begin{array}{l}\text { The implementation of the EU directive on insurance mediation }(2002 / 92 / E C) \\
\text { has been of great impact, implying the registration of about } 300,000 \text { insurance } \\
\text { intermediaries. } \\
\text { The German Chambers of Industry and Commerce (IHK) in the federal states } \\
\text { (länder) are responsible for the registration, licensing, and direct supervision of } \\
\text { insurance intermediaries. } \\
\text { BaFin has only an indirect supervisory role by controlling whether the insurers } \\
\text { cooperate with professional insurance intermediaries. } \\
\text { The licensing criteria and the few exceptions, the professional and good repute } \\
\text { requirements, as well as the financial capacity requirements are based on the } \\
\text { EU directive. } \\
\text { The legislation defines the sanctions for criminal and administrative offences, } \\
\text { which can be imposed by the IHK. The last resort measure is the withdrawal of } \\
\text { the license. }\end{array}$ \\
\hline Assessment & Largely Observed. \\
\hline Comments & $\begin{array}{l}\text { BaFin is not responsible for the direct supervision of the intermediaries. The } \\
\text { implementation of the relevant EU directive has been a major step in enhancing } \\
\text { the supervision of intermediaries. However, given the large number of } \\
\text { intermediaries and the federal structure, it is difficult to assess the effectiveness } \\
\text { of market conduct control performed by the competent supervisors. It is } \\
\text { advisable to carry out such an analysis and take appropriate actions to continue } \\
\text { improving the protection of policyholders at the point of sale. }\end{array}$ \\
\hline \multirow[t]{2}{*}{ Principle 25.} & Consumer protection \\
\hline & $\begin{array}{l}\text { The supervisory authority sets minimum requirements for insurers and } \\
\text { intermediaries in dealing with consumers in its jurisdiction, including foreign } \\
\text { insurers selling products on a cross-border basis. The requirements include } \\
\text { provision of timely, complete and relevant information to consumers both before } \\
\text { a contract is entered into through to the point at which all obligations under a } \\
\text { contract have been satisfied. }\end{array}$ \\
\hline Description & $\begin{array}{l}\text { The implementation of the insurance mediation directive forms the basis for } \\
\text { supervision of intermediaries in terms of duty of registration, qualification } \\
\text { requirements, rules of conduct, professional indemnity, and insurance. } \\
\text { BaFin, which is not responsible for the direct supervision of intermediaries in } \\
\text { Germany, performs an indirect supervision (see ICP 24). } \\
\text { The information to be given to the policyholders are extensive and detailed } \\
\text { including the cost of the products, information on the existence of a guarantee } \\
\text { fund or other compensation schemes, the general policy conditions, the main } \\
\text { features of the insurance benefits (whether or not the policyholder has a right of } \\
\text { cancellation and the conditions and details concerning the exercise of such } \\
\text { right), and contractual conditions for termination including any contractual } \\
\text { penalties. }\end{array}$ \\
\hline
\end{tabular}




\begin{tabular}{|c|c|}
\hline & $\begin{array}{l}\text { Information also includes a specific warning, where appropriate, that the financial } \\
\text { service being provided involves financial instruments - which are associated with } \\
\text { heightened risks due to their particular features or the processes involved, or } \\
\text { whose price is subject to fluctuations on the financial markets that are beyond } \\
\text { the primary insurer's control-and that past performance is not an indication of } \\
\text { future performance; the circumstances and risks to be outlined in each case. } \\
\text { Moreover, further information is established for certain life insurance, such as } \\
\text { occupational disability insurance, accident insurance with premium refund, and } \\
\text { health insurance, as well as when the policyholder is a consumer. In such a } \\
\text { case, the primary insurer is provide with a product information sheet containing } \\
\text { information, which is of particular significance to the conclusion or performance } \\
\text { of the insurance contract (such as the type of insurance contract on offer, a } \\
\text { description of the risk insured and of the excluded risks, and details on the level } \\
\text { of the premium in euros). } \\
\text { BaFin has a consumer complaints unit, which handles complaints submitted by } \\
\text { consumers and tries to help the complainants (about } 33 \text { percent had favorable } \\
\text { results). } \\
\text { The number of complaints is slightly decreasing (14,274 in } 2009 \text { ), probably also } \\
\text { because BaFin has no mediation power; while most primary insurers recognize } \\
\text { an ombudsman that can assume binding decisions up to a certain amount } \\
\text { (€10,000). It is free of charge for the policyholders. The ombudsman is a neutral } \\
\text { body that reports publicly on at least an annual basis. } \\
\text { The Federal Ministry for Food, Agriculture and Consumer Protection advises on } \\
\text { consumer protection-related aspects of policy. A quasi-governmental foundation } \\
\text { for consumer protection in financial markets is being established. Subnational } \\
\text { government and quasi-government agencies, such as chambers of commerce, } \\
\text { typically deal with individual complaints. } \\
\text { The Federal Data Protection Act (BDSG) lays down the privacy rules primary } \\
\text { insurers and intermediaries have to observe whilst dealing with data of their } \\
\text { customers. }\end{array}$ \\
\hline Assessment & Observed. \\
\hline Comments & $\begin{array}{l}\text { There are various tools which enable the consumers to solve possible issues } \\
\text { ranging from the complaints to BaFin, the help of consumers' associations and } \\
\text { the ombudsman. }\end{array}$ \\
\hline Principle 26. & $\begin{array}{l}\text { Information, disclosure \& transparency towards the market } \\
\text { The supervisory authority requires insurers to disclose relevant information on a } \\
\text { timely basis in order to give stakeholders a clear view of their business activities } \\
\text { and financial position and to facilitate the understanding of the risks to which } \\
\text { they are exposed. }\end{array}$ \\
\hline Description & $\begin{array}{l}\text { German insurers are required to publicly disclose their annual accounts, } \\
\text { management reports, group accounts, and group management reports. } \\
\text { Upon request, every policyholder of a primary insurer is entitled to receive the } \\
\text { annual accounts and status report of his contracting primary insurer in the } \\
\text { financial year following the year under review. }\end{array}$ \\
\hline Assessment & Observed. \\
\hline
\end{tabular}




\begin{tabular}{|c|c|}
\hline Comments & $\begin{array}{l}\text { In view of the incoming Solvency II regime, consideration should be given to the } \\
\text { enhancement of the disclosure requirements applied to insurers. } \\
\text { Time lags in the publication of aggregate financial sector data should be } \\
\text { shortened, and higher-frequency data would be useful (currently, some year-end } \\
\text { aggregates are published in the BaFin annual report that typically comes out in } \\
\text { May; quarterly investment positions are published with a few months lag, and } \\
\text { detailed annual data are published normally in November). Market participants } \\
\text { and others would appreciate the availability of preliminary data-perhaps when } \\
\text { over } 90 \text { percent of input data have been compiled-on a more timely basis. The } \\
\text { better provision of sectoral data would help stakeholders obtain a deeper } \\
\text { understanding of financial positions and risks. There is also likely to be demand } \\
\text { for publications of more market data and analysis by BaFin, which is both well- } \\
\text { informed and disinterested. }\end{array}$ \\
\hline Principle 27. & $\begin{array}{l}\text { Fraud } \\
\text { The supervisory authority requires that insurers and intermediaries take the } \\
\text { necessary measures to prevent, detect, and remedy insurance fraud. }\end{array}$ \\
\hline Description & $\begin{array}{l}\text { The legislation allows BaFin to supervise the administrative organization and } \\
\text { internal control of primary insurers and gives it adequate powers of enforcement } \\
\text { and cooperation with the competent criminal prosecution authorities and courts. } \\
\text { Insurers are obliged to report to BaFin any case of fraud (or possible fraud) they } \\
\text { detect (about } 250 \text { per year). Insurance fraud is addressed indirectly via internal } \\
\text { controls and compliance rules for the insurance undertakings. } \\
\text { Under the Criminal Code (StGB), it is a punishable offence to attempt to obtain } \\
\text { insurance benefits under false pretences for oneself or a third party. In individual } \\
\text { cases, simply providing false information in the insurance proposal may } \\
\text { constitute an attempt to defraud. There is also a subsidiary offence of abuse of } \\
\text { insurance, for which a person may be punishable if he damages, destroys, } \\
\text { impairs the use of, makes away with or relinquishes to someone else an object, } \\
\text { which has been insured against destruction, damage, impairment of use, loss or } \\
\text { theft, for the purpose of obtaining insurance benefits for himself or a third party. } \\
\text { The responsible persons at an insurer would also be liable to punishment if they } \\
\text { were to harm a potential beneficiary through fraud. } \\
\text { The VVG also foresee that giving false information, with intent to deceive, in the } \\
\text { insurance proposal or in the notification of claim relieves the insurer of its liability } \\
\text { for payment. However, if the insured gives false information in the case of third- } \\
\text { party liability motor insurance, the injured party is still entitled to the minimum } \\
\text { level of protection. } \\
\text { The German Insurance Association (GDV) provides its members with training on } \\
\text { combating fraud and organized meetings between the undertakings for sake of } \\
\text { an exchange of experiences on the issue. It has drawn up advice for its } \\
\text { members on fraud prevention in the case of certain individual risks. It also } \\
\text { manages a database to help combat fraud. }\end{array}$ \\
\hline Assessment & Observed. \\
\hline Comments & The core requirements are in place. \\
\hline
\end{tabular}




\begin{tabular}{|c|c|}
\hline \multicolumn{2}{|l|}{ AML/CFT } \\
\hline Principle 28. & $\begin{array}{l}\text { AML/CFT } \\
\text { The supervisory authority requires insurers and intermediaries, at a minimum } \\
\text { those insurers and intermediaries offering life insurance products or other } \\
\text { investment related insurance, to take effective measures to deter, detect and } \\
\text { report money laundering and the financing of terrorism consistent with the } \\
\text { Recommendations of the Financial Action Task Force on Money Laundering } \\
\text { (FATF). }\end{array}$ \\
\hline Description & 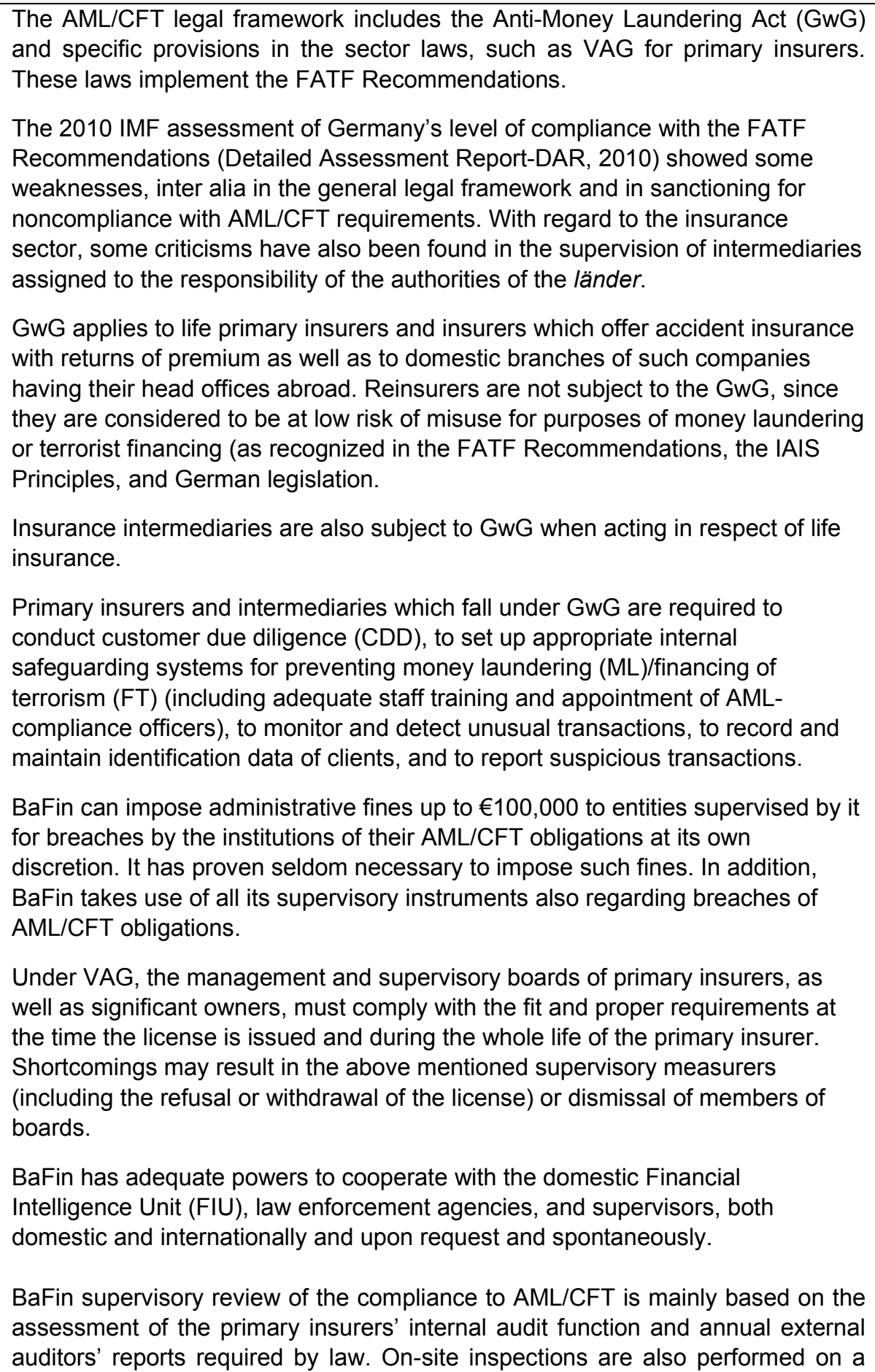 \\
\hline
\end{tabular}




\begin{tabular}{|c|c|}
\hline & 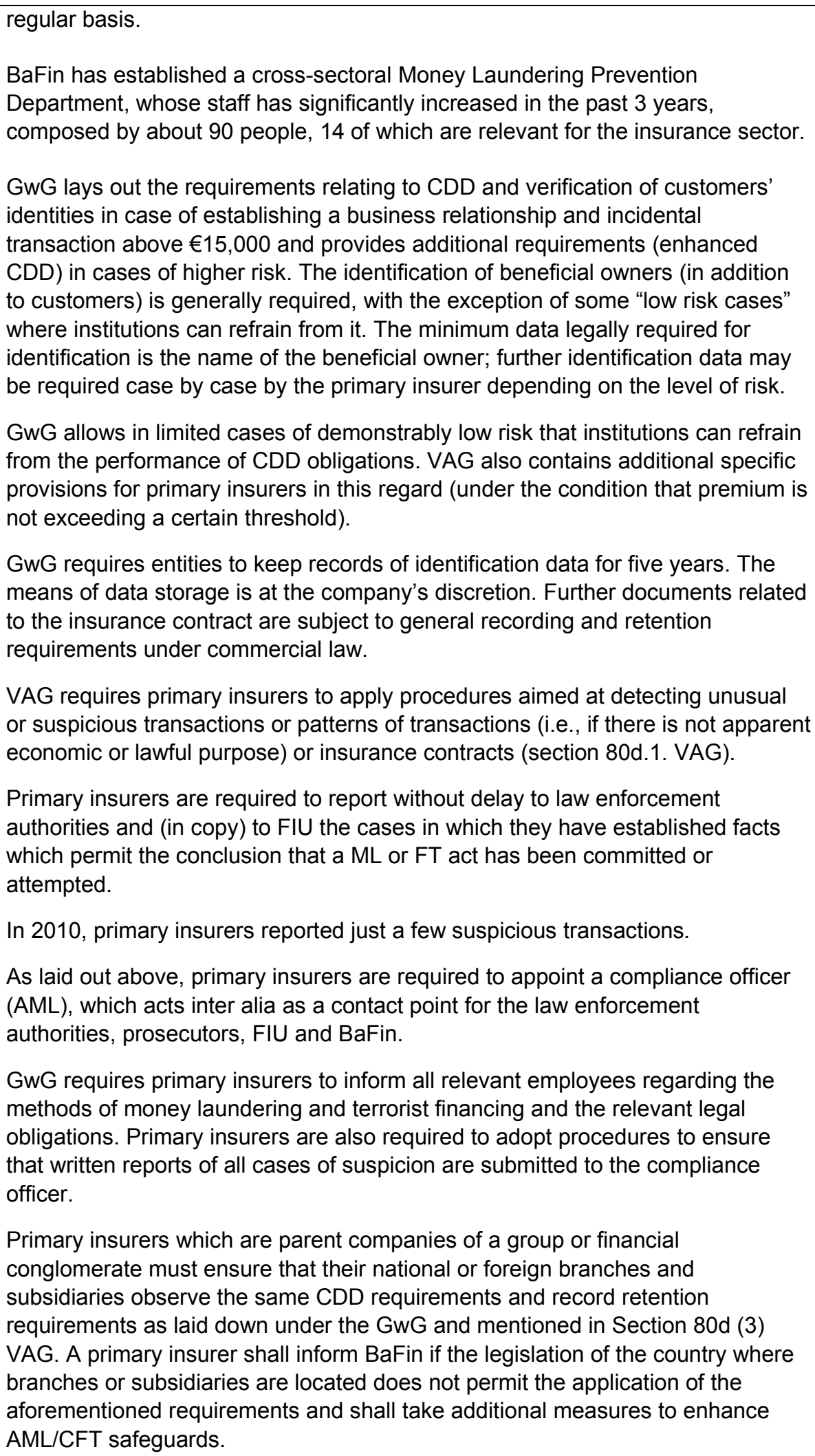 \\
\hline Assessment & Largely observed. \\
\hline Comments & Germany is currently in the process of addressing the weaknesses identified by \\
\hline
\end{tabular}


the IMF/FATF assessment in February 2010. This will have significant effect on both primary insurers (the relevant amendments are contained in the law implementing the second EU-E-money directive, which will come into effect in the beginning of March 2011), and insurance intermediaries (the relevant amendments of the AML-Act will come into effect later in 2011). However, at the time of the assessment, certain gaps remained, and evidence of remedial actions taken regarding insurance intermediaries was lacking. 